Article

\title{
Not Only Health: Environmental Pollution Disasters and Political Trust
}

\author{
Xun Gong ${ }^{1}$, Shenggang Yang ${ }^{1}$ and Min Zhang ${ }^{2, *}$ \\ 1 College of Finance and Statistics, Hunan University, Changsha 410082, China; \\ b1218s004@hnu.edu.cn (X.G.); sgyang@hnu.edu.cn (S.Y.) \\ 2 Business School of Hunan University, Changsha 410082, China \\ * Correspondence: zhangmin87828@hnu.edu.cn; Tel.: +86-731-8868-5302 \\ Academic Editor: Yongrok Choi \\ Received: 21 February 2017; Accepted: 7 April 2017; Published: 10 April 2017
}

\begin{abstract}
Over the past 30 years, the economy of China has sustained rapid growth. However, the extensive development pattern severely deteriorates the ecological environment, which has been recognized as adverse effects on citizens' physical and mental health. Simultaneously, the political trust in China has been in decline after staying at a high level for a long time. In this paper, we state that, in addition to health issues, environmental pollution can also lead to important political consequences. Using statistics on the occurrence of environmental pollution disasters and a nationally representative survey database in China, we find that environmental pollution disasters can negatively affect citizens' trust of the government. This relationship persists after a series of endogenous tests and robustness checks. Path analysis indicates that this relationship can be partially mediated by the increase in citizens' environmental awareness. The cross-sectional analyses on individual characteristics demonstrate that the negative effect of environmental pollution disasters on political trust is less pronounced for female citizens and citizens who are communist party members. Finally, we report that the government's positive attitudes and activities in resolving environmental pollution problems can partially offset the negative effect of environmental pollution disasters on political trust.
\end{abstract}

Keywords: environmental pollution disasters; political trust; environmental awareness

\section{Introduction}

China has achieved great success in economic development in the past 30 years; the average growth rate of the GDP is higher than9\% [1,2]. However, there are numerous studies that state that China's rapid growth is at the cost of resource consumption and environmental pollution, which cause serious economic losses, social conflicts and health costs in China [3,4]. Air, water, soil, photochemical, and noise pollution is serious in China, and the negative and persistent effects on people's health over a long period have been confirmed [5,6]. For example, according to a report by the World Bank, China has been the largest contributor of sulphur oxides and chlorofluorocarbons to the atmosphere since 2001 [7]. By using the quasi-experiment of China's Huai River Policy, Chen et al. (2013) [8] found that air pollution had a significant negative effect on people's life expectancies (about 5.5 years less). Furthermore, as one of the most important momentums of economic growth, rapid urbanization results in tremendous pressure on waste disposal, which is a considerable challenge for soil protection and food security in China [9]. In this case, Khan et al. (2008) [10] confirmed that the heavy metals in contaminated soils had significant health risks for Chinese people. In addition to physical health, mental health is also affected by pollution. The PM2.5 in smog can impact the human brain structure, which further negatively affects people's moods and cognitive competence [11,12]. Granieri (2015) also 
indicates that asbestos exposure has a negative impact on the physical health of the population and on its psychological and community components [13].

Although numerous studies have investigated the effects of environmental pollution on people's health, much fewer concerns are expressed regarding the impact on political issues. In political regimes, political trust is a central component of the study [14,15]. According to the definition of Miller and Listhaug (1990) [16], political trust is the "judgment of the citizenry that the system and the political incumbents are responsive, and will do what is right even in the absence of constant scrutiny". Political trust has been confirmed with substantial effects on the design and execution of public policy [17], the establishment and maintaining of good democratic governance [18], and the success of building a competent state in the background of globalization [19]. Political trust, in this regard, emerges as one of the most important factors upon which the legitimacy and sustainability of political systems are built. Even though China generally is not considered as a democracy [20,21], sufficient political trust and popular support should also be important factors affecting sociopolitical stability and persistent economic growth.

In current research, two theories compete as explanations for the origins of political trust, one is Cultural Theories, and another one is Institutional Theories. In Cultural Theories, trust in political institutions is hypothesized to be exogenous [22]. On the contrary, the Institutional Theories hold that citizens' political trust is endogenous to the performance of the political system [23,24]. By using the Fall of Communism in Europe as a quasi-experiment, Mishler and Rose (2001) [25] concluded that the Institutional Theories are superior in explaining the origins of political trust. This means that political trust will vary with citizens' satisfaction of the function and efficiency of the political system [26,27]. The persistent decline in political trust in western democracy countries since the mid-1960s also provides supportive evidence of the Institutional Theories $[28,29]$.

Different from the ubiquitous downward trend in the advanced industrialized democracies, the political trust in China was maintained at a high level for quite a long time. Wang (2005) [15] indicated that the rapid economic development is the key reason that greatly enhances public support for the government. Recently, however, the level of political trust in China has been in decline. The rapid modernization promotes citizens' higher expectation for public goods provided by the government. The slowing-down of economic growth, the widespread official corruption, and citizens' increasing sense of political empowerment erode the Chinese government's political legitimacy and regime stability [21,30]. Nevertheless, the impacts of environmental pollution and ecological hazards on political trust are insufficiently discussed.

Environmental rights are basic and fundamental human rights [31]. The government is responsible for protecting citizens' environmental rights and for challenging all threats to environmental resources. Once environmental rights are abused, people can personally perceive the undesirable consequences, disappointment and sense of deprivation that follow. Guglielmucciet al. (2015) carefully review related literature and demonstrated that technological disasters and industrial pollution usually lead to anxiety, somatization, rage, depression and post-traumatic conditions, which undermine victims' own sense of psychic integrity [32].If the government cannot effectively resolve the problems, or more seriously, those problems are in fact induced by the government, it is a reasonable prediction that citizens' confidence and trust of the government would be significantly reduced[33].

This paper aims to investigate whether and to what extent environmental pollution can decrease citizens' political trust. Considering that environmental pollution disasters are more likely to be perceived by citizens, the occurrence of emerging environmental events is used to measure the extent of environmental pollution. Based on a widely used survey database, the China Family Panel Study, we conduct empirical analyses based on the Ologit model. The results confirm that citizens in regions with more serious environmental pollution disasters expressed weaker supportive attitudes toward the government. Furthermore, we realize that the estimated relationship may suffer from endogeneity problems. To alleviate the concern of the endogeneity issues, we adopt a change model and Lewbel's constructed instrument method and include possibly omitted variables. A battery of tests suggests 
that the negative association between environmental pollution disasters and citizens' political trust is robust with respect to possible endogeneity issues.

In subsequent path analyses, we further explore possible mechanisms of the relationship between environmental pollution disasters and political trust. The empirical results indicate that citizens' environmental awareness is a significant mediation. This confirms our prediction that the occurrence of environmental pollution disasters can inspire citizens' critical awareness of environmental issues, which further negatively affect their political trust. In addition, we also investigate the moderating effects of citizens' traits on the relationship between environmental pollution disasters and political trust. Specifically, a group of individual characteristics, such as gender, age, education level, income level, and political identity, is tested. The empirical results show that the political supportive level of female and party member citizens is less likely to be affected by environmental pollution disaster events.

Finally, we check whether the government's positive response to the environmental pollution disasters can mitigate the negative effects on citizens' political trust. Specific to this study, two factors are considered: governments' attitudes and efforts in resolving environmental problems. We find that in regions where local governments have more communication with citizens about environmental issues or invest more in governing environmental pollution, the negative effects of environmental pollution disasters are less pronounced because the residents have recognized the governments' responsiveness and efforts in solving environmental problems.

This study contributes to the existing literature in several ways. First, unlike most previous studies that focus on the effect of environmental pollution on people's health, our study chooses to conduct analyses from the perspective of political trust. Our study provides direct evidence that environmental pollution affects not only citizens' health but also people's political trust. In addition to confirming the negative effects of environmental pollution disasters on political trust, we also find that this relationship varies with citizens' characteristics.

Second, we examine the influence channel and provide some applicable ways to diminish the negative influence. Instead of the physical health channel, the increase in citizens' environmental awareness is confirmed as a significant mechanism. This shows that the influence of shocks on the mind induced by disastrous environmental events is the main driving factor that decreases political trust. In the case where citizens' environmental awareness and critical sense increase, concealing information or trying to fool citizens should be bad choices. Instead, more effective communication and positive actions in resolving environmental problems may be much more effective ways to redeem a damaged reputation.

Third, to our knowledge, this study is the first to use the context of China, the largest emerging market and the second largest economy, to examine the impacts of environmental pollution disasters on citizens' political trust. Political trust is a traditional but important research topic. However, there have been a limited number of empirical studies on political trust in China [21]. In consideration that there are significant differences in institutional settings and political systems, the findings derived from developed countries may not fit well with those from underdeveloped or developing countries. As a result, focusing on the context of China, which is regarded as the largest developing country, our study adds to the extant literature on the political consequence of serious environmental pollution.

The remainder of this paper is organized as follows. Section 2 introduces some historical environmental pollution disaster events and institutional background of China. Section 3 discusses the data, measurement methods, and empirical models used in this study. Section 4 reports the empirical results and our main findings. Section 5 presents additional analyses and a variety of robustness checks. Finally, Section 6 draws some conclusions and discusses the limitations. 


\section{Institutional Background}

In the early 20th century, several disastrous environmental pollution events happened in developed countries, such as the London Smog Disasters [34], Los Angeles Smog [35], and Japan Minamata Disease events [36]. These events are not merely historic stories. They spurred the citizens' realization of the harm of pollution and significantly improved people's environmental awareness. Some events even greatly accelerated the perfection of the legal system (such as the pass of Clean Air Act in the United Kingdom and U.S.).

As the largest developing country, China now faces similar problems. Its miraculous growth in economics encompasses high investment, high resource consumption and high pollutant emissions [4,37]. Recently, a number of environmental pollution disasters occurred across vast parts of China [38,39]. For example, in 2004, one firm, Sichuan Chemical Co., Ltd. (Chengdu, China), illegally emitted waste water into the Tuojiang River, resulting in severe contamination. This event caused over 300 million RMB direct economic losses, and more than one million citizens' water supplies were cut off. Subsequent reports indicate that at least 5 years are required to recover the ecological environment. Another typical event occurred in 2005. The explosion of a factory of the China Petroleum Group led to 76 civilian casualties. In addition, over 100 tons of organic pollutants flowed into the Songhua River, which caused very serious consequences. The security of water of several cities along the riverside was threatened, and millions of residents' daily lives were affected. Some rumors of the severity of this event even caused panic through the buying of drinking water. This event also polluted the downstream regions in the KhabarovskKrai of Russia and caused serious negative international effects. Later, the State Council of China punished 12 responsible persons, and the director of China's State Environmental Protection Administration (predecessor of current Ministry of Environmental Protection) had to take responsibility and resign. In the following 5 years, 7.84 billion RMB were invested in the treatment of the pollution of the Songhua River. Compared with the inconspicuous pollution in daily lives, these disastrous environmental pollution events usually cause immediate losses and induce much greater social shocks [40-42].

To properly monitor and cope with these environmental pollution disasters, in 2005, the Ministry of Environmental Protection issued the National Contingency Plan for Emergent Environmental Events (hereafter Contingency Plan). The Contingency Plan formally names these momentous pollution events as "emergent environmental events", and provides specific definition and identifying criterions. According to the Contingency Plan, emergent environmental events are " ... those events caused by pollutant emission, natural events or industrial accidents, which may decrease environmental quality, endanger citizens' health and property safety, induce ecological destruction, or trigger significant social impacts".

The Contingency Plan classifies emergent environmental events into four levels by the influential scope, severity and losses of events: extremely severe events (Level I), severe events (Level II), large events (Level III), and general events (Level IV). Please refer to Appendix B for the detailed assessment criteria of the levels of emergent environmental events. Table 1 provides the detailed statistics of the occurrence of emergent environmental events for each province in 2011 and 2013. (Due to a lack of space, only the statistics of emergent environmental events in study sample periods are presented. Other data are available on the website of the National Bureau of Statistics of China (www.stats.gov.cn).) We can see that there are significant regional differences in the distribution of emergent environmental events, which provide a good setting to test our inferences. 
Table 1. Statistics pertaining to the occurrence of emergent environmental events for each province.

\begin{tabular}{|c|c|c|c|c|c|c|c|c|}
\hline & \multicolumn{4}{|c|}{ Year $=2011$} & \multicolumn{4}{|c|}{ Year $=2013$} \\
\hline & Level I & Level II & Level III & Level IV & Level I & Level II & Level III & Level IV \\
\hline Anhui & 0 & 0 & 1 & 11 & 0 & 0 & 1 & 5 \\
\hline Beijing & 0 & 0 & 0 & 36 & 0 & 0 & 0 & 16 \\
\hline Hujian & 0 & 0 & 0 & 8 & 0 & 0 & 0 & 13 \\
\hline Gansu & 0 & 0 & 0 & 0 & 0 & 0 & 0 & 11 \\
\hline Guangdong & 0 & 3 & 0 & 23 & 0 & 0 & 1 & 4 \\
\hline Guangxi & 0 & 0 & 0 & 0 & 0 & 1 & 1 & 14 \\
\hline Guizhou & 0 & 1 & 1 & 5 & 0 & 0 & 0 & 9 \\
\hline Hainan & 0 & 0 & 0 & 1 & 0 & 0 & 0 & 4 \\
\hline Hebei & 0 & 0 & 2 & 14 & 0 & 0 & 0 & 3 \\
\hline Henan & 0 & 1 & 0 & 24 & 0 & 0 & 0 & 17 \\
\hline Heilongjiang & 0 & 0 & 0 & 5 & 0 & 0 & 0 & 0 \\
\hline Hubei & 0 & 0 & 0 & 0 & 0 & 0 & 2 & 5 \\
\hline Hunan & 0 & 0 & 0 & 0 & 0 & 0 & 1 & 2 \\
\hline Jilin & 0 & 0 & 0 & 0 & 0 & 0 & 0 & 1 \\
\hline Jiangsu & 0 & 0 & 1 & 26 & 0 & 0 & 1 & 124 \\
\hline Jiangxi & 0 & 0 & 1 & 7 & 0 & 1 & 0 & 4 \\
\hline Liaoning & 0 & 0 & 0 & 2 & 0 & 0 & 1 & 11 \\
\hline Neimenggu & 0 & 0 & 0 & 14 & 0 & 0 & 0 & 4 \\
\hline Ningxia & 0 & 0 & 0 & 1 & 0 & 0 & 1 & 2 \\
\hline Qinghai & 0 & 0 & 0 & 1 & 0 & 0 & 0 & 2 \\
\hline Shandong & 0 & 0 & 0 & 0 & 0 & 0 & 1 & 4 \\
\hline Shanxi & 0 & 0 & 0 & 11 & 0 & 1 & 0 & 12 \\
\hline Shanxi & 0 & 0 & 0 & 2 & 0 & 0 & 0 & 118 \\
\hline Shanghai & 0 & 0 & 0 & 197 & 0 & 0 & 1 & 250 \\
\hline Sichuan & 0 & 1 & 1 & 23 & 0 & 0 & 0 & 14 \\
\hline Tianjin & 0 & 0 & 0 & 1 & 0 & 0 & 0 & 0 \\
\hline Xizang & 0 & 0 & 0 & 0 & 0 & 0 & 0 & 0 \\
\hline Xinjiang & 0 & 0 & 0 & 6 & 0 & 0 & 0 & 10 \\
\hline Yunnan & 0 & 0 & 0 & 1 & 0 & 0 & 0 & 2 \\
\hline Zhejiang & 0 & 0 & 3 & 28 & 0 & 0 & 1 & 25 \\
\hline Chongqing & 0 & 0 & 0 & 18 & 0 & 0 & 0 & 11 \\
\hline Total & 0 & 6 & 10 & 465 & 0 & 3 & 12 & 697 \\
\hline
\end{tabular}

\section{Sample, Measurement and Empirical Model}

\subsection{A Brief Overview of CFPS}

Many of the key variables in this paper are measured by using the China Family Panel Study (hereafter CFPS). CFPS is a large-scale, almost nationally representative panel survey project conducted by the Institute of Social Science Survey (hereafter ISSS) at Peking University. The National Bureau of Statistics of China, the National Population and Family Planning Commission, and numerous universities and research institutes actively participate in the design and operation of CFPS. This project covers 25 provinces of China, which represent over $95 \%$ of the Chinese population in mainland China. (Neimenggu, Xinjiang, Xizang, Hainan, Ningxia, and Qinghai province are not included in the survey objects of the CFPS.) CFPS has been widely applied in academic studies in both science and social science fields [43-48], which confirm the reliability of this survey database.

The baseline wave of CFPS was formally conducted in 2010 (hereafter CFPS-2010). The sample for the CFPS-2010 through a multi-stage probability is drawn with implicit stratification. It is designed to be multi-stage so as to reduce the operational cost of the survey and to allow for studies of social contexts. Each subsample in the CFPS study is drawn through three stages: county (or equivalent), then village (or equivalent), then household.

Interviews were conducted using computer assisted personal interviewing (CAPI) technology, provided by the Survey Research Center (SRC) at the University of Michigan. The CAPI and its associated survey-management system enables the researchers to design a fairly complex interview schedule tailored to each member of the household and reduces measurement error while at the 
same time allows the management team at the ISSS to closely monitor the quality of the interviews in the field.

In the 2010 baseline survey, the CFPS successfully interviewed almost 15,000 families and almost 30,000 individuals within these families, for an approximately response rate of $79 \%$. The CFPS respondents are tracked through annual follow-up surveys. For brevity, the specific questions and items setting of CFPS are not included in this paper. However, they are all available on the website of CFPS: http:/ /www.isss.edu.cn/cfps/. (We greatly acknowledge one referee's suggestion for presenting more information about the CFPS.)

One noteworthy issue is that, although the baseline wave of CFPS was formally conducted in 2010, the questions that measure the respondents' political trust and other attitudes were only asked in the 2nd wave of CPFS in 2012 (hereafter CFPS-2012) and 3rd wave of CFPS in 2014 (hereafter CFPS-2014). Hence, we built our sample based on the CFPS-2012 and CFPS-2014 surveys.

\subsection{Measurement of Political Trust}

The primary dependent variable in this study is the citizens' trust in the government. One question was asked in both CFPS-2012 and CFPS-2014, translated as follows:

Please rate to what degree you trust local government officials.

$(0=$ extremely low trust; $10=$ extremely high trust $)$

Hence, we use the feedback grades of this question as a proxy for the respondents' political trust level. This measurement was also adopted in Chen and Yang (2015) [43], who discuss the effects of the great Chinese famine on citizen's political trust. Here, we need to mention that, in the institutional background of political sensitivity of eliciting trust in the central government in mainland China, citizens' political trust in central government or the whole political system is difficult to determine. Nevertheless, trust in local government can be a strong predictor of trust in political institutions. Based on the institutional settings of democratic countries, previous literature has confirmed that lack of trust towards specific officials can transform itself into a distrust of different political institutions, and ultimately, of the political system as a whole [16,18,49-57]. Even though China is not considered as a democratic country by western scholars, it is still true that most people do not directly interact with central government. Local governments and officials are those who have direct interactions with citizens. By using data collected in rural China, Li (2011) [58] also confirmed that the distrust in government leaders can strengthen citizens' demand in reforming the current political system.

The still on-going anti-corruption campaign in China can also provide some supportive evidence. We know that during this campaign, a number of high-ranking officials (we call them big tigers, such as Bo Xilai, Zhou Yongkang, and Ling Jihua, etc.) were arrested and sanctioned. However, the central government further emphasizes the investigation and treatment of corrupt, low-ranking local officials (we call them flies). The reason is that the low-ranking local officials are those people who directly interact with citizens, and their administrative power has a significant influence on citizens' daily life. Hence, their behaviors and corruption may have a greater influence on citizens' perceived corruption of the whole political system. This also provides supportive evidence that local officials have important effects on people's political trust. We acknowledge one referee's suggestion to provide more evidence in justifying the rationality of the measurement of political trust.)

Therefore, even with flaws, we consider this measurement is still acceptable.

\subsection{Measurement of Environmental Pollution Disasters}

According to the introduction in the previous section, environmental pollution disasters in China are defined as emergent environmental events and categorized into four levels. In addition to the statistics of emergent environmental events, the Ministry of Environmental Protection also 
simultaneously discloses the most severe pollution cases annually. Through checking these severe pollution cases in the recent five years, we find that most of them are water and soil pollution caused by human and business factors. Disasters are measured based on the statistics on the occurrence of emergent environmental events in the previous year. These data are obtained from the National Database of the National Bureau of Statistics of China (data.stats.gov.cn). Considering that there are significant differences in the severity among different level events, simply using occurrence times of emergent environmental events as the measurement of Disasters may not be enough. Hence, we choose to build a simple index to incorporate the severity into our measurement simultaneously. Higher weights are given to higher emergency events, which usually lead to more severe consequences. Specifically, Disasters are defined as follows:

\section{Disasters $=2 *$ \# of Level II events +1.5 * \# of Level III events+ \# of Level IV events}

Because there is no Level I event in our sample, a Level I event is not included in Equation (1). We also use the simple sum method or other weight strategies for robustness, but there was no qualification change in the empirical results.

\subsection{Empirical Model}

We apply the following model to examine the effect of emergent environmental events on citizens' political trust:

$$
\begin{aligned}
\text { Trust }_{i, t}=\beta_{0}+ & \beta_{1} \text { Disasters }_{i, t-1}+\beta_{2} \text { Gender }_{i}+\beta_{3} \text { LogAge }_{i, t-1}+\beta_{4} \text { LogAge }_{i, t-1}^{2} \\
& +\beta_{5} \text { Educ }_{i, t-1}+\beta_{6} \text { Party }_{i, t-1}+\beta_{7} \text { Job }_{i, t-1}+\beta_{8} \text { Urban }_{i, t-1} \\
& +\beta_{9} \text { Income }_{i, t-1}+\beta_{10} \text { Status }_{i, t-1}+\beta_{11} \text { Organization }_{i, t-1} \\
& +\beta_{12} \text { Conflict }_{i, t-1}+\beta_{13} \text { LogPerGDP }_{i, t-1}+\beta_{14} \text { Density }_{i, t-1} \\
& +\beta_{15} \text { Density }_{i, t-1}^{2}+\beta_{16} \text { Mindex }_{i, t-1}+\text { Yeardummy }^{2} \\
& + \text { Regiondummy }
\end{aligned}
$$

where $i$ and $t$ represent the individual and time subscript indicators, respectively. The ordered logistic model (Ologit) is estimated with the consideration that Trust is an ordered variable. Robust heteroskedasticity is adopted. Please refer to "Appendix" for more detailed definitions of all included variables.

To control for individual demographic factors that have been confirmed to impact political trust [26], we include a series of individual characteristic variables. Gender is an indicator variable that equals one if the individual is a male. LogAge is calculated as the natural logarithm of an individual's age. We also incorporate the square term of LogAge, LogAge2, to control for the possible nonlinear relationship between age and political trust. Educ is an ordered variable that ranges from 0 to 8 , which is a proxy for the individual's education level. Party is a dummy variable that indicates whether the respondent is a member of communist party, which is the absolute majority political party in China. $J o b$ equals one if the citizen is engaged in non-agricultural work, and zero otherwise. Urban equals one if the individual lives in a city, and zero otherwise. Income is an ordered variable measured as a citizen's self-evaluation of his/her income in a local place; this variable ranges from one to five: one means the lowest level, five means the highest level. (In both CFPS-12 and CFPS-14, one question was asked: "In which level do you think you belong to based on your personal income? $0=$ extremely low; $5=$ extremely high". The reason we do not adopt a quantitative income measurement is that a lot of respondents refused to directly disclose their actual income. To maintain more useable observations and diminish the concern of selection bias, we chose to use this measurement method. A similar measurement strategy was adopted by Wang (2005) [15]). Similarly, Status is an ordered variable measured as a citizen's self-evaluation of his/her social status in a local place; this variable ranges from one to five: one means the lowest level, five means the highest level. Organization is a dummy variable that indicates whether the individual belongs to any organizations, such as political parties (except the Communist party), industrial associations, or religious groups, etc. Most of these 
organizations are under the regulation of the government, and Ma et al. (2015) [59] even confirmed that industrial associations can help entrepreneurs to obtain formal political identities and springboards. Conflict is an ordered variable that measures individual's adverse experiences in getting along with the local government in the past, which may greatly decrease his/her supportive attitude toward the government. In CFPS-12 and CFPS-14, the following questions were asked: "In the previous year, have you ever been unfairly treated by governmental officials?", "In the previous year, have you ever had any conflicts with governmental officials?", "In the previous year, have you ever had the experience that government irresponsibly excuses or delays issues within duties?", and "In the previous year, have you ever had the experience that government irresponsibly charged extra fees for issues within duties?". Conflict equals two if the respondent personally experienced any of above mentioned incidents; Conflict equals one if the respondent did not have a personal experience of the above mentioned events, but learnt that some of them happened somewhere; Conflict equals zero if the respondent had never experienced or heard about these events before.

Considering that regional development conditions may also affect local citizen's political trust, we also incorporated several variables to control for the regional disparity. These data were obtained from the China Statistical Yearbook issued by the National Bureau of Statistics of China. LogPerGDP is the natural logarithm of GDP per person, which presents the regional income level. To control for the regional urbanization level, we incorporate Density, which is measured as the natural logarithm of urban population density. Considering that there may be a nonlinear relationship between urban scale and citizens' life satisfaction[60], we also included the square term of Density, Density2.We further include the widely accepted marketization index (Mindex) developed by Fan et al. (2011) [61] as a proxy for the institutional environments in different provinces. Higher values of Mindex indicate faster regional marketization processes and better regional institutional environment. The above-mentioned regional variables were measured at the end of the year before the survey was conducted. We also included year and region indicators to control for year and regional fixed effects. All continuous variables were winsorized at $1 \%$ and $99 \%$ levels. All $\mathrm{t}$-values were calculated based on robust standard errors.

\section{Empirical Results}

\subsection{Descriptive Statistics}

Table 2 provides the summary statistics of key variables. The average political trust level is 4.910 . Considering that Trust ranges from zero to ten, it shows that Chinese citizens' political trust level is relatively low. The top quartile of Conflict equals 1, which indicates that at least $25 \%$ people heard or personally experienced adverse conflicts with governments.

With respect to individual characteristics, $52 \%$ respondents in our sample are male, and the average Age is 25.89. The mean value and top quartile of $E d u c$ are 2.63 and 3, respectively, which shows that most people in our sample did not receive higher education. We can see that $45 \%$ respondents are working in non-agricultural jobs, and $43 \%$ people hold urban hukou. The mean values of Income and Status are 2.4 and 2.81, respectively. The Party statistics show that $2 \%$ of the respondents in our sample are party members.

Table 3 provides the Pearson correlations of variables. The key variables of interest in our study are occurrence of emergent environmental events (Disasters) and citizens' political trust level (Trust). The correlation matrix shows that the Disasters variable is negatively correlated with Trust, providing preliminary support for our prediction. Furthermore, the correlation coefficients among most control variables are generally low. The variance inflation factors (VIF) of all independent variables are far below 10, implying that there is no serious multicollinearity problem [62]. 
Table 2. Summary statistics for key variables.

\begin{tabular}{|c|c|c|c|c|c|c|c|c|}
\hline Variables & $\mathbf{N}$ & Mean & Sd & P25 & P50 & P75 & Min & Max \\
\hline Trust & 42,056 & 4.910 & 2.570 & 3 & 5 & 7 & 0 & 10 \\
\hline Disasters & 42,056 & 25.89 & 52.91 & 2 & 11 & 26 & 0 & 251.5 \\
\hline Gender & 42,056 & 0.520 & 0.500 & 0 & 1 & 1 & 0 & 1 \\
\hline Age & 42,056 & 46.32 & 14.32 & 36 & 46 & 57 & 16 & 93 \\
\hline Educ & 42,056 & 2.630 & 1.460 & 2 & 3 & 3 & 0 & 8 \\
\hline Party & 42,056 & 0.020 & 0.120 & 0 & 0 & 0 & 0 & 1 \\
\hline$J o b$ & 42,056 & 0.450 & 0.500 & 0 & 0 & 1 & 0 & 1 \\
\hline Urban & 42,056 & 0.430 & 0.500 & 0 & 0 & 1 & 0 & 1 \\
\hline Income & 42,056 & 2.400 & 0.980 & 2 & 3 & 3 & 1 & 5 \\
\hline Status & 42,056 & 2.810 & 1.020 & 2 & 3 & 3 & 1 & 5 \\
\hline Organization & 42,056 & 0.150 & 0.350 & 0 & 0 & 0 & 0 & 1 \\
\hline Conflict & 42,056 & 0.440 & 0.760 & 0 & 0 & 1 & 0 & 2 \\
\hline PerGDP & 42,056 & 41,049 & 18,502 & 28,661 & 34,174 & 50,807 & 16,413 & 99,607 \\
\hline Density & 42,056 & 7.990 & 0.400 & 7.770 & 8.030 & 8.270 & 7.220 & 8.670 \\
\hline Mindex & 42,056 & 6.040 & 1.600 & 5.010 & 6.190 & 6.870 & 3.380 & 9.950 \\
\hline
\end{tabular}

Table 3. Pearson correlation matrix a,b,c

\begin{tabular}{|c|c|c|c|c|c|c|c|c|c|c|c|c|c|c|c|c|}
\hline Variables & & VIF & 1 & 2 & 3 & 4 & 5 & 6 & 7 & 8 & 9 & 10 & 11 & 12 & 13 & 14 \\
\hline Trust & 1 & 1.11 & 1 & & & & & & & & & & & & & \\
\hline Disasters & 2 & 1.92 & $-0.04^{* * *}$ & 1 & & & & & & & & & & & & \\
\hline Gender & 3 & 1.05 & $-0.03^{* * *}$ & 0 & 1 & & & & & & & & & & & \\
\hline LogAge & 4 & 1.16 & $0.13^{* * *}$ & $0.03^{* * *}$ & $0.03^{* * *}$ & 1 & & & & & & & & & & \\
\hline Educ & 5 & 1.34 & $-0.12^{* * *}$ & $0.11^{* * *}$ & $0.15^{* * *}$ & $-0.31^{* * *}$ & 1 & & & & & & & & & \\
\hline Party & 6 & 1.11 & $0.01 * * *$ & -0.01 & $0.06 * * *$ & $-0.03 * * *$ & $0.09 * * *$ & 1 & & & & & & & & \\
\hline $\mathrm{Job}$ & 7 & 1.08 & $-0.07^{* * *}$ & $0.12 * * *$ & $-0.02 * * *$ & $-0.03^{* * *}$ & $0.11^{* * *}$ & $-0.02 * * *$ & 1 & & & & & & & \\
\hline Urban & 8 & 1.23 & $-0.12 * * *$ & $0.21 * * *$ & $-0.01^{* *}$ & $-0.03^{* * *}$ & $0.27^{* * *}$ & $0.03^{* * *}$ & $0.23^{* * *}$ & 1 & & & & & & \\
\hline Income & 9 & 1.29 & $0.11^{* * *}$ & 0.01 & $0.07^{* * *}$ & $-0.03^{* * *}$ & $0.04^{* * *}$ & $0.02^{* * *}$ & $-0.06^{* * *}$ & $-0.05^{* * *}$ & 1 & & & & & \\
\hline Status & 10 & 1.32 & $0.18^{* * *}$ & $-0.01 * *$ & -0.01 & $0.10^{* * *}$ & $-0.03 * * *$ & $0.01 * *$ & $-0.05^{* * *}$ & $-0.09 * * *$ & $0.46^{* * *}$ & 1 & & & & \\
\hline Organization & 11 & 1.20 & $0.01^{* * *}$ & $0.05^{* * *}$ & $0.12^{* * *}$ & $-0.06 * * *$ & $0.27^{* * *}$ & $0.31^{* * *}$ & $0.04^{* * * *}$ & $0.13^{* * *}$ & $0.06^{* * *}$ & $0.06^{* * *}$ & 1 & & & \\
\hline Conflict & 12 & 1.05 & $-0.19^{* * *}$ & $-0.02 * * *$ & $0.08^{* * *}$ & $-0.03^{* * *}$ & $0.02 * * *$ & 0 & 0 & -0.01 & $-0.02 * * *$ & $-0.04 * * *$ & $0.02^{* * *}$ & 1 & & \\
\hline LogperGDP & 13 & 5.50 & $-0.06^{* * *}$ & $0.54^{* * *}$ & 0 & $0.04^{* * *}$ & $0.18^{* * *}$ & $-0.02 * * *$ & $0.12^{* * *}$ & $0.27^{* * *}$ & 0.01 & $-0.04 * * *$ & $0.03^{* * *}$ & $-0.05^{* * *}$ & 1 & \\
\hline Density & 14 & 1.66 & 0 & $0.17^{* * *}$ & 0.01 & $-0.03^{* * *}$ & $-0.01^{* *}$ & $0.02 * * *$ & $0.04^{* * *}$ & $-0.03^{* * *}$ & $0.02 * * *$ & $0.04^{* * *}$ & $0.03^{* * *}$ & $0.04^{* * *}$ & $-0.41^{* * *}$ & 1 \\
\hline Mindex & 15 & 4.22 & $-0.03 * * *$ & $0.51^{* * *}$ & 0 & $0.03^{* * *}$ & $0.15^{* * *}$ & $-0.02 * * *$ & $0.12 * * *$ & $0.29 * * *$ & $0.01 *$ & $-0.03^{* * *}$ & $0.03 * * *$ & $-0.05^{* * *}$ & $0.87^{* * *}$ & $-0.31^{* * *}$ \\
\hline
\end{tabular}

a * denotes $p<0.1$; ** denotes $p<0.05$; and ${ }^{* * *}$ denotes $p<0.01 .{ }^{\mathrm{b}}$ VIF denotes "Variance Inflation Factors". ${ }^{\mathrm{c}}$ Please refer to Appendix B for the detailed definitions of variables. 


\subsection{Regression Results}

The baseline regression results of the effects of environmental pollution disasters on citizens' political trust are represented in Table 4. In column (1), we run a single regression without control variables. In column (2), we incorporate individual level variables. In column (3), we further control for several aspects of regional disparities. In column (4), we control for year and regional fixed effects. We find that all coefficients of Disasters are statistically significant. This shows that consistent with our intuition, with more environmental pollution disasters, citizens tend to distrust the government.

Table 4. Baseline regressions results ${ }^{\mathrm{a}, \mathrm{b}, \mathrm{c}}$.

\begin{tabular}{|c|c|c|c|c|}
\hline & (1) & (2) & (3) & (4) \\
\hline Disasters & $\begin{array}{l}-0.001 \text { *** } \\
(-8.51)\end{array}$ & $\begin{array}{l}-0.001^{* * *} \\
(-4.66)\end{array}$ & $\begin{array}{l}-0.001 * \\
(-1.84)\end{array}$ & $\begin{array}{l}-0.002 * * \\
(-2.30)\end{array}$ \\
\hline Gender & & $\begin{array}{l}-0.045^{* *} \\
(-2.55)\end{array}$ & $\begin{array}{l}-0.051^{* * *} \\
(-2.85)\end{array}$ & $\begin{array}{l}-0.056^{* * *} \\
(-3.14)\end{array}$ \\
\hline Logage & & $\begin{array}{l}-4.304^{* * *} \\
(-8.63)\end{array}$ & $\begin{array}{l}-4.141^{* * *} \\
(-8.31)\end{array}$ & $\begin{array}{l}-4.551^{* * *} \\
(-9.06)\end{array}$ \\
\hline Logage2 & & $\begin{array}{l}0.655^{* * * *} \\
(9.67)\end{array}$ & $\begin{array}{l}0.637^{* * * *} \\
(9.41)\end{array}$ & $\begin{array}{l}0.695^{* * *} \\
(10.18)\end{array}$ \\
\hline Educ & & $\begin{array}{l}-0.061^{* * *} \\
(-9.12)\end{array}$ & $\begin{array}{l}-0.049^{* * *} \\
(-7.26)\end{array}$ & $\begin{array}{l}-0.046^{* * *} \\
(-6.79)\end{array}$ \\
\hline Party & & $\begin{array}{l}0.143^{* *} \\
(2.05)\end{array}$ & $\begin{array}{l}0.125^{*} \\
(1.78)\end{array}$ & $\begin{array}{l}0.159 * * \\
(2.29)\end{array}$ \\
\hline$J o b$ & & $\begin{array}{l}-0.148^{* * *} \\
(-8.25)\end{array}$ & $\begin{array}{l}-0.147^{* * *} \\
(-8.15)\end{array}$ & $\begin{array}{l}-0.146^{* * *} \\
(-7.83)\end{array}$ \\
\hline Urban & & $\begin{array}{l}-0.303^{* * *} \\
(-16.04)\end{array}$ & $\begin{array}{l}-0.313^{* * *} \\
(-16.21)\end{array}$ & $\begin{array}{l}-0.307^{* * *} \\
(-15.58)\end{array}$ \\
\hline Income & & $\begin{array}{l}0.084^{* * * *} \\
(7.68)\end{array}$ & $\begin{array}{l}0.086^{* * *} \\
(7.80)\end{array}$ & $\begin{array}{l}0.075^{* * *} \\
(6.83)\end{array}$ \\
\hline Status & & $\begin{array}{l}0.256^{* * *} \\
(22.63)\end{array}$ & $\begin{array}{l}0.255^{* * *} \\
(22.45)\end{array}$ & $\begin{array}{l}0.245^{* * *} \\
(21.50)\end{array}$ \\
\hline Organization & & $\begin{array}{l}0.182^{* * *} \\
(7.02)\end{array}$ & $\begin{array}{l}0.184^{* * *} \\
(7.12)\end{array}$ & $\begin{array}{l}0.192^{* * *} \\
(7.37)\end{array}$ \\
\hline Conflict & & $\begin{array}{l}-0.425^{* * *} \\
(-34.96)\end{array}$ & $\begin{array}{l}-0.432^{* * *} \\
(-35.57)\end{array}$ & $\begin{array}{l}-0.450 \\
(-36.56)\end{array}$ \\
\hline LogperGDP & & & $\begin{array}{l}-0.564^{* * *} \\
(-11.89)\end{array}$ & $\begin{array}{l}0.203 \\
(0.52)\end{array}$ \\
\hline Density & & & $\begin{array}{l}6.408^{* * * *} \\
(7.08)\end{array}$ & $\begin{array}{l}5.556 \\
(0.55)\end{array}$ \\
\hline Density2 & & & $\begin{array}{l}-0.408^{* * *} \\
(-7.19)\end{array}$ & $\begin{array}{l}-0.346 \\
(-0.54)\end{array}$ \\
\hline Mindex & & & $\begin{array}{l}0.133^{* * *} \\
(11.99)\end{array}$ & $\begin{array}{l}0.011 \\
(0.24)\end{array}$ \\
\hline Yeardummy & No & No & No & Yes \\
\hline Regiondummy & No & No & No & Yes \\
\hline$N^{\circ}$ & 42,056 & 42,056 & 42,056 & 42,056 \\
\hline
\end{tabular}

a T-statistics are reported in parentheses; $t$-values are calculated based on robust standard errors. ${ }^{\mathrm{b}}$ Significance at the $1 \%$ level is denoted as $* *, 5 \%$ level as ${ }^{* *}$, and $10 \%$ level as ${ }^{*}$. ${ }^{c}$ Please refer to Appendix B for the detailed definitions of variables.

As for the control variables, most results are consistent with previous studies [63-65]. For example, the coefficient of Gender is significantly negative, which is consistent with the idea that men hold more distrustful opinions of government than women in China [63]. Both coefficients of Age and Age2 are significant but with contradictory symbols, which suggest a U-shape relationship between citizens' age and political trust. This result is consistent with the previous finding that, in the developing world, age has a nonlinear impact on political trust [64]. The positive coefficient of Income and negative coefficient of $E d u c$ also confirm the conclusion that higher income levels are usually associated with 
higher political trust, but higher education with lower trust [65]. Similar to Income, the estimated coefficient of Status is also positive and significant. Both higher income and social status make people feel satisfied with current life, and prompt trust of the government.

For party members, it is not surprising to find their significantly higher political trust level under the condition that the communist party has worked as the ruling party for over 60 years. In China, a large portion of various organizations is under the regulation of the government, or directly founded by the government's affiliations. Hence, most of them have statutes to guide members' "sense of political correctness" in China, which is in support of the governance of the communist party and government. In addition, joining associations can be good opportunities to build political connections with the government, which may bring potential benefits. This underlying conflict of interest may also improve their preference in trusting government.

Interestingly, we find that the coefficients of Urban and Job are both negative, which indicate that rural citizens and people who work in the agricultural industry have higher political trust levels. There are two possible reasons: First, the Chinese government's consistent preferential policies in supporting the development of rural places and agricultural industries. For example, in 2014, over 50 farmer-benefitting policies were issued or updated, and more than 200 billion RMB were directly subsidized to farmers. These favorable policies may be important driven factors of farmers' high political trust. Second: relatively lower costs of living in rural places. The pressure of survival for citizens living in cities is much more intense, especially in the background of the Chinese urban property price, which is too expensive to afford. In contrast, people living in the country are less likely to feel anxious complain about the government's administrative performance.

For the regional variables, we can see that their coefficients are all significant in column (3), which indicates that these factors indeed have effects on citizens' political trust. The coefficients are insignificant in column (4), indicating that these factors have been included in regional fixed effects.

\subsection{Endogeneity}

To summarize, the main regressions preliminary support our prediction. However, as with any empirical research, there are several caveats. First of all, there could be some unmeasurable individual-level characteristics that are related to both political trust and environmental pollution disasters, which may lead to omitted variable bias. Second, although most emergent environmental events are unpredictable, we should admit that they cannot be seen as pure exogenous events. The possibly related regional differences, such as the ruling efficiency of government, the momentum of economic development, and social atmosphere, are difficult to measure and perfectly control. Even though we have controlled for regional fixed effects, it may not be enough.

To eliminate the interference of those individual and regional characteristics that are stable but unobservable, we employ a change analysis to explore the effect of environmental pollution disasters on citizens' political trust. The CFPS-12 and CFPS-14 provide us a strongly balanced short panel to conduct change analysis. $\Delta$ denotes the changes in corresponding variables between CFPS-12 and CFPS-14. Those indicator variables with little time variants, such as Gender, Educ, and Region dummies, are not included in the regression of change analysis. Table 5 provides the results of the change analysis. As shown, the regression coefficient of $\Delta$ Disasters is significantly negative, which indicates a negative relationship between environmental pollution disasters and political trust. This result supports our main finding. 
Table 5. Result of the change analysis a,b,c .

\begin{tabular}{|c|c|}
\hline & $\Delta$ Trust \\
\hline$\Delta$ Disasters & $\begin{array}{l}-0.002 \text { *** } \\
(-3.65)\end{array}$ \\
\hline$\Delta$ Logage & $\begin{array}{l}4.897 \\
(0.43)\end{array}$ \\
\hline$\Delta$ Logage2 & $\begin{array}{l}-1.605 \\
(-0.73)\end{array}$ \\
\hline SIncome & $\begin{array}{l}0.036^{* * *} \\
(2.65)\end{array}$ \\
\hline$\Delta$ Status & $\begin{array}{l}0.123^{* * *} \\
(9.24)\end{array}$ \\
\hline$\Delta$ Organization & $\begin{array}{l}-0.034 \\
(-0.82)\end{array}$ \\
\hline$\Delta$ Conflict & $\begin{array}{l}-0.164 \text { *** } \\
(-10.77)\end{array}$ \\
\hline$\triangle$ LogperGDP & $\begin{array}{l}0.069 \\
(0.36)\end{array}$ \\
\hline$\Delta$ Density & $\begin{array}{l}2.056 \\
(0.33)\end{array}$ \\
\hline$\Delta$ Density2 & $\begin{array}{l}-0.132 \\
(-0.34)\end{array}$ \\
\hline$\Delta$ Mindex & $\begin{array}{l}-0.010 \\
(-0.32)\end{array}$ \\
\hline$N$ & 16,958 \\
\hline
\end{tabular}

a T-statistics are reported in parentheses; $t$-values are calculated based on robust standard errors. ${ }^{\mathrm{b}}$ Significance at the $1 \%$ level is denoted as ${ }^{* * *}, 5 \%$ level as ${ }^{* *}$, and $10 \%$ level as ${ }^{*} .{ }^{c} \Delta$ denotes the change of corresponding variable. Please refer to Appendix B for the detailed definitions of variables.

Furthermore, we also apply IV regression to mitigate the endogeneity concerns. Considering the extreme difficulties in finding valid instruments, we adopt a technique developed by Rigobon (2003) [66], as applied by Lewbel (2012) [67], which exploit the presence of heteroskedasticity in the regression residuals [68-71].

Because this approach is not well known, we first provide a brief intuitive discussion. Assume that we are interested in estimating the following model:

$$
\begin{gathered}
y_{1}=a_{1}+b_{1} X+c y_{2}+\varepsilon_{1} \\
y_{2}=a_{2}+b_{2} X+\varepsilon_{2}
\end{gathered}
$$

where $y_{2}$ is the endogenous variable and $X$ is a matrix of exogenous variables. In addition to the standard assumptions that $\varepsilon_{1}$ and $\varepsilon_{2}$ are uncorrelated with $X$ and are also uncorrelated with each other (i.e., $E\left(X \varepsilon_{1}\right)=E\left(X \varepsilon_{2}\right)=\operatorname{cov}\left(\boldsymbol{X}, \varepsilon_{1} \varepsilon_{2}\right)=0$ ), if we add an assumption in the presence of heteroskedasticity (i.e., $\operatorname{cov}\left(\boldsymbol{X}, \varepsilon_{2}^{2}\right) \neq 0$ ), then we can use $\boldsymbol{X} \varepsilon_{2}$ as an instrument for $y_{2}$. The reason is that assuming that $\operatorname{cov}\left(\boldsymbol{X}, \varepsilon_{1} \varepsilon_{2}\right)=0$ can guarantee that $X \varepsilon_{2}$ is uncorrelated with $\varepsilon_{1}$ (the exogeneity condition for valid instruments), whereas the presence of heteroskedasticity $\left(\operatorname{cov}\left(\boldsymbol{X}, \varepsilon_{2}^{2}\right) \neq 0\right)$ can guarantee that $X \varepsilon_{2}$ is correlated with $y_{2}$ (the relevance condition). Fulfilling these two conditions ensures the validity of $X \varepsilon_{2}$. In short, this method can generate valid instruments if the existing of heteroskedasticity is confirmed.

In an untabulated analysis, we confirm the presence of heteroskedasticity in model (4) $\left(\operatorname{cov}\left(X, \varepsilon_{2}^{2}\right) \neq 0\right)$, which makes us confident in using Lewbel's method. The IV regression results are reported in Table 6 . They show that Disasters have negative and statistically significant effect on the political trust. 
Table 6. IV regression based on Lewbel's method ${ }^{a, b, c}$.

\begin{tabular}{|c|c|}
\hline & Trust \\
\hline Disasters & $\begin{array}{l}-0.002 * \\
(-1.93)\end{array}$ \\
\hline Gender & $\begin{array}{l}-0.101^{* * *} \\
(-4.14)\end{array}$ \\
\hline Logage & $\begin{array}{l}-6.304^{* * *} \\
(-9.20)\end{array}$ \\
\hline Logage2 & $\begin{array}{l}0.964^{* * *} \\
(10.37)\end{array}$ \\
\hline$E d u c$ & $\begin{array}{l}-0.071 \text { *** } \\
(-7.58)\end{array}$ \\
\hline Party & $\begin{array}{l}0.241^{* *} \\
(2.56)\end{array}$ \\
\hline$J o b$ & $\begin{array}{l}-0.203^{* * *} \\
(-7.99)\end{array}$ \\
\hline Urban & $\begin{array}{l}-0.420 \\
(-15.62)\end{array}$ \\
\hline Income & $\begin{array}{l}0.100 * * * \\
(6.80)\end{array}$ \\
\hline Status & $\begin{array}{l}0.315^{* * *} \\
(21.24)\end{array}$ \\
\hline Organization & $\begin{array}{l}0.263^{* * *} \\
(7.41)\end{array}$ \\
\hline Conflict & $\begin{array}{l}-0.615^{* * *} \\
(-37.69)\end{array}$ \\
\hline LogperGDP & $\begin{array}{l}0.202 \\
(0.38)\end{array}$ \\
\hline Density & $\begin{array}{l}7.324 \\
(0.53)\end{array}$ \\
\hline Density2 & $\begin{array}{l}-0.454 \\
(-0.53)\end{array}$ \\
\hline Mindex & $\begin{array}{l}0.001 \\
(0.01)\end{array}$ \\
\hline Constant & $\begin{array}{l}-17.340 \\
(-0.32)\end{array}$ \\
\hline Yeardummy & Yes \\
\hline Regiondummy & Yes \\
\hline$N$ & 42,056 \\
\hline
\end{tabular}

a T-statistics are reported in parentheses; $\mathrm{t}$-values are calculated based on robust standard errors. ${ }^{\mathrm{b}}$ Significance at the $1 \%$ level is denoted as ${ }^{* * *}, 5 \%$ level as ${ }^{* *}$, and $10 \%$ level as *. ${ }^{c}$ Please refer to Appendix B for the detailed definitions of variables.

Finally, to mitigate the endogeneity caused by possibly omitted correlated variables, we add to the empirical model a number of variables, including degree of corruption, social trust level, religious atmosphere, and Confucianism, which may potentially affect both the occurrence of environmental pollution disasters and citizens' political trust.

Numerous studies have documented the negative effects of corruption on citizens' supportive attitudes of the government $[65,72-75]$. One important reason is that corruption would make the government operate inefficiently. Under this condition, the weakening in the monitoring function of government may increase the possibility of the occurrence of environmental pollution disasters. Therefore, the corruption level in different provinces is included. We check the China Procuratorate Yearbook issued by China Supreme People's Procuratorate, and use the number of cases on government officials' corruption and misconducts to measure the corruption level in each province.

Another possible factor is social trust. Kaase (1999) [76] found a significant positive relationship between interpersonal trust and political trust. On the other side, higher social trust usually relates 
to higher social capital, which can be an effective force to suppress unsocial activities [77]. Therefore, following the measuring methods of $\mathrm{Wu}$ et al. (2014) [78], we use the people's enthusiasm in voluntary blood donations to measure social trust.

Lehrer (2004) [79] indicates that religion has a significant influence on various economic and demographic behaviors of individuals and families. Several studies confirm that religion affects both individual's political activism and environmental awareness $[80,81]$. Therefore, we also incorporate the religious atmosphere into the regression. Following Chen et al. (2013) [82] and Du et al. (2014) [83], Religion is measured as the proportion of religious members in the provincial-level Chinese People's Political Consultative Conference.

In addition to religion, the cultural atmosphere may also greatly affect people's attitudes and activities. According to the Cultural theories, trust in political institutions is hypothesized to originate outside the political sphere in long-standing and deeply seeded beliefs about people that are rooted in cultural norms. Therefore, we also try to address this potential concern. As the most influential cultural school, Confucianism has guided Chinese people's attitudes and behaviors for thousands years [84]. (We should acknowledge that it is quite difficult to control for all cultural factors in China. In different regions, various local cultures and traditions exist. Hence, it is nearly impossible to control them exhaustively. However, controlling for regional fixed effects may partially eliminate the concern. We sincerely appreciate one referee's comments on the discussion of cultural influence.) Confucian philosophy emphasizes the importance of trust in others and elevates it to one of the eight basic moral principles [85]. Tan and Tambyah (2011) [86] also demonstrate the important influence of Confucianism on both generalized trust and political trust. Hence, the influence of Confucianism is also under consideration. Du (2014) [87] summarizes seven Confucianism centers: Lu (Qufu of Shandong Province), Luo (Luoyang of Henan Province), Shu (Chengdu of Sichuan Province), Min (Sanming and Longyan of Fujian Province), Taizhou (Dongtai of Jiangsu Province), Zhedong (Eastern regions of Zhejiang Province such as Ningbo and Shaoxing), and Linchuan (Linchuan of Jiangxi Province), in where citizens are more likely to be influenced by the philosophy of Confucianism. Following his method, Confucianism equals one if people live in the above-mentioned provinces, and zero otherwise.

The results are presented in Table 7. They show that, after controlling for these variables, there is still a strong negative relationship between environmental pollution disasters and political trust.

Table 7. Results after incorporating corruption, social trust, religion, and Confucianism ${ }^{\mathrm{a}, \mathrm{b}, \mathrm{c}}$.

\begin{tabular}{lllll}
\hline & $\mathbf{( 1 )}$ & $\mathbf{( 2 )}$ & $\mathbf{( 3 )}$ & $\mathbf{( 4 )}$ \\
\hline \multirow{2}{*}{ Disasters } & $-0.002^{* *}$ & $-0.002^{* *}$ & $-0.002^{* * *}$ & $-0.002^{* *}$ \\
Gender & $(-2.30)$ & $(-2.30)$ & $(-2.32)$ & $(-2.30)$ \\
& $-0.056^{* * *}$ & $-0.056^{* * *}$ & $-0.067^{* * *}$ & $-0.056^{* * *}$ \\
Logage & $(-3.14)$ & $(-3.14)$ & $(-3.51)$ & $(-3.14)$ \\
& $-4.551^{* * *}$ & $-4.551^{* * *}$ & $-4.588^{* * *}$ & $-4.551^{* * *}$ \\
Logage2 & $(-9.06)$ & $(-9.06)$ & $(-8.34)$ & $(-9.06)$ \\
Educ & $0.695^{* * *}$ & $0.695^{* * *}$ & $0.701^{* * *}$ & $0.695^{* * *}$ \\
Party & $(10.18)$ & $(10.18)$ & $(9.39)$ & $(10.18)$ \\
Job & $-0.046^{* * *}$ & $-0.046^{* * *}$ & $-0.048^{* * *}$ & $-0.046^{* * *}$ \\
Urban & $(-6.79)$ & $(-6.79)$ & $(-6.37)$ & $(-6.79)$ \\
& $0.159^{* *}$ & $0.159^{* *}$ & $0.170^{* *}$ & $0.159^{* *}$ \\
\hline & $(2.29)$ & $(2.29)$ & $(2.22)$ & $(2.29)$ \\
& $-0.146^{* * *}$ & $-0.146^{* * *}$ & $-0.134^{* * *}$ & $-0.146^{* * *}$ \\
& $(-7.83)$ & $(-7.83)$ & $(-6.67)$ & $(-7.83)$ \\
& $-0.307^{* * *}$ & $-0.307^{* * * *}$ & $-0.303^{* * *}$ & $-0.307^{* * *}$ \\
& $(-15.58)$ & $(-15.58)$ & $(-14.58)$ & $(-15.58)$ \\
\hline
\end{tabular}


Table 7. Cont.

\begin{tabular}{lllll}
\hline & $\mathbf{( 1 )}$ & $\mathbf{( 2 )}$ & $\mathbf{( 3 )}$ & $\mathbf{( 4 )}$ \\
\hline \multirow{2}{*}{ Income } & $0.075^{* * *}$ & $0.075^{* * *}$ & $0.077^{* * *}$ & $0.075^{* * *}$ \\
& $(6.83)$ & $(6.83)$ & $(6.36)$ & $(6.83)$ \\
Status & $0.245^{* * *}$ & $0.245^{* * *}$ & $0.253^{* * *}$ & $0.245^{* * *}$ \\
Organization & $(21.50)$ & $(21.50)$ & $(20.00)$ & $(21.50)$ \\
Conflict & $0.192^{* * *}$ & $0.192^{* * *}$ & $0.176^{* * *}$ & $0.192^{* * *}$ \\
& $(7.37)$ & $(7.37)$ & $(6.29)$ & $(7.37)$ \\
LogperGDP & $-0.450^{* * *}$ & $-0.450^{* * *}$ & $-0.459^{* * *}$ & $-0.450 * * *$ \\
Density & $(-36.56)$ & $(-36.56)$ & $(-34.15)$ & $(-36.56)$ \\
Density2 & 0.203 & 0.203 & 0.223 & 0.203 \\
Mindex & $(0.52)$ & $(0.52)$ & $(0.52)$ & $(0.52)$ \\
Corruption & 5.556 & 5.556 & 4.231 & 5.556 \\
Socialtrust & $(0.55)$ & $(0.55)$ & $(0.40)$ & $(0.55)$ \\
Religion & -0.346 & -0.346 & -0.264 & -0.346 \\
Confucianism & $(-0.54)$ & $(-0.54)$ & $(-0.40)$ & $(-0.54)$ \\
Yeardummy & 0.011 & 0.011 & 0.021 & 0.011 \\
Regiondummy & $(0.24)$ & $(0.24)$ & $(0.39)$ & $(0.24)$ \\
N & 0.372 & & & \\
\hline
\end{tabular}

a T-statistics are reported in parentheses; $t$-values are calculated based on robust standard errors. ${ }^{\mathrm{b}}$ Significance at the $1 \%$ level is denoted as ${ }^{* * *}, 5 \%$ level as ${ }^{* *}$, and $10 \%$ level as *. ${ }^{\mathrm{c}}$ Please refer to Appendix B for the detailed definitions of variables.

\subsection{Robustness}

We further conduct a series of robustness checks and report the results in Table 8:

(1) As mentioned before, we calculate Disasters based on different weights on different levels of emergent events. For robustness, we alternatively use different weight methods or directly adopt the number of emergent events to measure the severity of environmental pollution disasters. The results are reported in Panel A of Table 8. The conclusions are the same as those presented before.

(2) To eliminate the concern of potential serial correlation issues, we re-run regressions after clustering by region or by individual. The results are reported in Panel B of Table 8. These treatments make above results even more statistical significant.

(3) Considering that local pollution conditions may also affect citizens' political trust, we incorporate this factor as a control variable. Because it is quite difficult to use one variable as a proxy for the regional pollution condition, we use several variables as proxies for different types of pollution. The severity of air pollution is measured by using the emission amount of sulfur dioxide. The severity of water pollution is measured by using the emission amount of waste water. The severity of soil pollution is measured by using the increasing amount of land desertification. The results are reported in Panel C of Table 8. After solely or simultaneously controlling for these variables, our results still hold.

(4) We further control for some possibly related regional characteristics, such as the unemployment rate, crime rate, and efficiency of the transportation system. The results are reported in Panel D of Table 8.Generally, after controlling for all above variables, there is no qualitative change in our findings. 
(5) Considering that citizens in Beijing can simultaneously perceive the influence of the local Beijing government and the central government of China, their political trust level may be quite different from other citizens. To address this potential effect, we drop the observations pertaining to living in Beijing and re-run the regression. The result is presented in Panel E of Table 8. We can see that our conclusion still holds. (We acknowledge one referee's comments pointing out this limit.)

Table 8. Further robustness checks ${ }^{a, b, c}$.

\begin{tabular}{|c|c|}
\hline Treatment Methods & Regression Results of Disasters \\
\hline \multicolumn{2}{|c|}{ Panel A Adopt alternative measurements of environmental pollution disasters } \\
\hline Add larger weights for more severe events & $\begin{array}{l}-0.02^{* *} \\
(-2.17)\end{array}$ \\
\hline Only use common events to denote disasters & $\begin{array}{l}-0.02^{* *} \\
(-1.97)\end{array}$ \\
\hline \multicolumn{2}{|c|}{ Panel B Adopt clustering methods to calculate regression standard errors } \\
\hline Cluster by region & $\begin{array}{l}-0.02 * \\
(-1.69)\end{array}$ \\
\hline Cluster by individuals & $\begin{array}{l}-0.02 \\
(-2.39)\end{array}$ \\
\hline Two-way cluster by region and individuals & $\begin{array}{c}-0.02^{* * *} \\
(-2.59)\end{array}$ \\
\hline \multicolumn{2}{|l|}{ Panel C Controlling for local pollution conditions } \\
\hline Controlling for local air pollution & $\begin{array}{l}-0.02 * * \\
(-1.97)\end{array}$ \\
\hline Controlling for local water pollution & $\begin{array}{l}-0.02^{*} \\
(-1.83)\end{array}$ \\
\hline Controlling for local land pollution & $\begin{array}{c}-0.02 * * * \\
(-2.62)\end{array}$ \\
\hline Simultaneously controlling for local pollution & $\begin{array}{l}-0.02 * * \\
(-2.07)\end{array}$ \\
\hline \multicolumn{2}{|l|}{ Panel D Controlling for other regional characteristics } \\
\hline Controlling for local unemployment rate & $\begin{array}{l}-0.02 * * \\
(-2.15)\end{array}$ \\
\hline Controlling for local crime rate & $\begin{array}{l}-0.02 * * \\
(-2.08)\end{array}$ \\
\hline Controlling for regional transportation system efficiency & $\begin{array}{l}-0.02 * * \\
(-2.23)\end{array}$ \\
\hline Simultaneously controlling for regional characteristics & $\begin{array}{l}-0.02 * * \\
(-2.01)\end{array}$ \\
\hline \multicolumn{2}{|l|}{ Panel E Diminishing the influence of political center } \\
\hline Drop the observations who live in Beijing & $\begin{array}{l}-0.02^{* *} \\
(-2.10)\end{array}$ \\
\hline \multicolumn{2}{|c|}{$\begin{array}{l}{ }^{a} \text { For brevity, only the regression coefficients and } t \text {-statistics of environmental pollution disasters are presented. } \\
\text { Except for Panel C and Panel D, which include more control variables, the untabulated control variables are all } \\
\text { same as the original regressions. }{ }^{b} \text { T-statistics are reported in parentheses; except for Panel B, all other t-values are } \\
\text { calculated based on robust standard errors. }{ }^{c} \text { Significance at the } 1 \% \text { level is denoted as }{ }^{* * *}, 5 \% \text { level as } * * \text {, and } 10 \% \\
\text { level as }{ }^{*} \text {. }\end{array}$} \\
\hline
\end{tabular}

\section{Additional Research}

\subsection{Possible Mechanisms}

In this section, we try to investigate from which channel the environmental pollution disasters negatively affect citizens' political trust. From our first instinct, citizens' health could be a possible channel, because there is strong evidence confirming that environmental pollution can significantly 
harm people's health $[5,6,9]$. However, in untabulated results, we do not find a significant relationship between the emergent environmental events and citizens' health. Hence, we further consider this question from the perspective of citizens' consciousness of environmental pollution disasters.

Although the environmental problems in China are very serious, there are large disparities among citizens with respect to the awareness of environmental disasters. Some people are concerned about the natural environment and realize the serious consequences of pollution. However, some hold the opinion that pollution is acceptable, especially in the case that the growth of China's economy greatly depends on resource consumption [37]. Munro (2014) [88] indicated that there were only 6\% Chinese citizens considered as victims of environmental pollution in 2006. A large portion of Chinese people are used to environmental pollution, or even see pollution as a "usual" condition.

However, different from normal types of pollution, which are difficult to perceive, environmental pollution disasters usually cause instant but tremendous negative consequences on environments and people's lives. Hence, we infer that these events may greatly inspire citizens' awareness of the harm of environmental pollution, and further cast people's doubts on the reliability of government. We conduct a path analysis to explore this inference. As introduced by Bhattacharya et al. (2011) [89], the path analysis decomposes the correlation between the causal variable (Disasters in this paper) and the outcome variable (Trust in this paper) into direct and indirect paths. We consider the Awareness variable, which denotes the citizens' concern of environmental issues, as the mediator. Awareness is measured based on one question asked in both CFPS-2012 and CFPS-2014, translated as follows:

In your mind, how serious is the environmental pollution problem in China? $(0=$ not serious; $10=$ extremely serious $)$

We use the feedback grade of this question as a proxy for the respondents' environmental awareness. The procedures of the path analysis are provided in Figure 1. Three paths should be tested: direct path, mediation path, and indirect path.

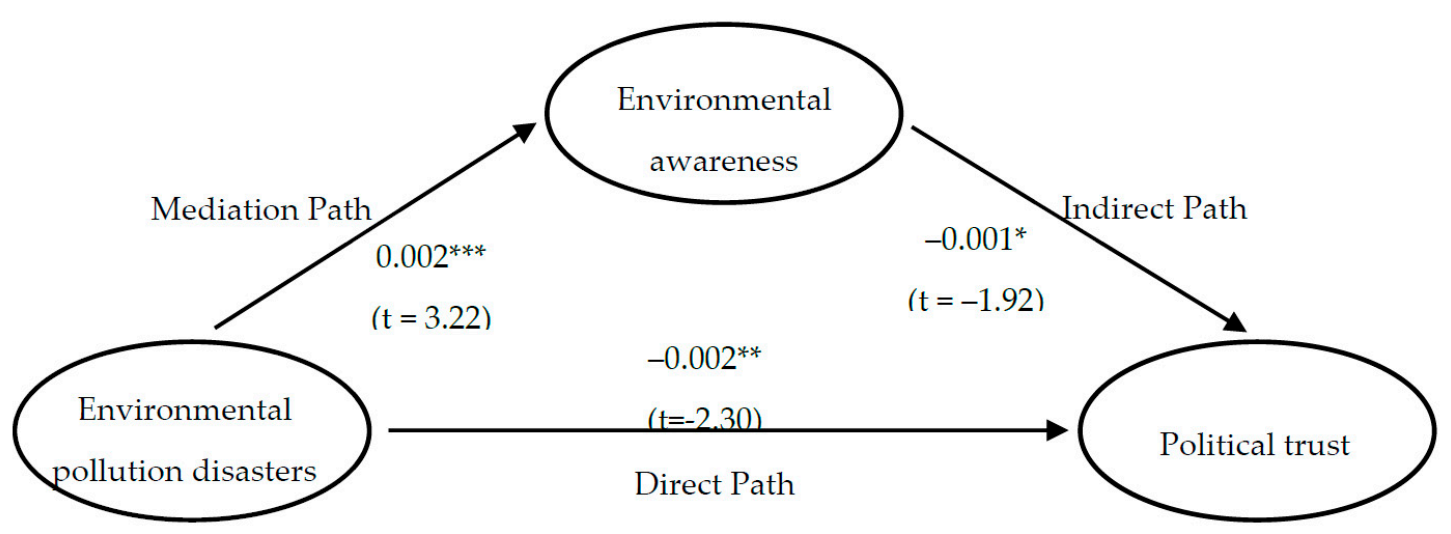

Figure 1. Procedures of path analysis.

Table 9 presents the results of our path analysis. Column (1), (2) and (3) report the regression results of the direct path, mediation path, and indirect path, respectively. Results in column (1) and (2) show that Disasters have significant effects on both citizens' political trust and environmental awareness. In column (3), both Awareness and Disasters are included in the regression. The estimated coefficients of Awareness and Disasters are both significant, which preliminary support our prediction. Table 10 shows the formal tests on the mediation effects. Both the Sobel and Goodman statistics are significant, which confirm the mediation role of environmental awareness in the relationship between environmental pollution disasters and political trust. 
Table 9. Path analysis with environmental awareness as a mediator ${ }^{\mathrm{a}, \mathrm{b}, \mathrm{c}}$.

\begin{tabular}{|c|c|c|c|}
\hline & (1) & (2) & (3) \\
\hline & Trust & Awareness & Trust \\
\hline Awareness & & & $\begin{array}{l}-0.050^{* * *} \\
(-12.79)\end{array}$ \\
\hline Disasters & $\begin{array}{l}-0.002 * * \\
(-2.30)\end{array}$ & $\begin{array}{l}0.002^{* * *} \\
(3.22)\end{array}$ & $\begin{array}{l}-0.001 * \\
(-1.92)\end{array}$ \\
\hline Gender & $\begin{array}{l}-0.056^{* * *} \\
(-3.14)\end{array}$ & $\begin{array}{l}0.070 * * * \\
(3.92)\end{array}$ & $\begin{array}{l}-0.053^{* * *} \\
(-2.97)\end{array}$ \\
\hline Logage & $\begin{array}{l}-4.551^{* * *} \\
(-9.06)\end{array}$ & $\begin{array}{l}2.995^{* * *} \\
(6.11)\end{array}$ & $\begin{array}{l}-4.328^{* * *} \\
(-8.53)\end{array}$ \\
\hline Logage2 & $\begin{array}{l}0.695^{* * *} \\
(10.18)\end{array}$ & $\begin{array}{l}-0.520 * * * \\
(-7.78)\end{array}$ & $\begin{array}{l}0.656^{* * *} \\
(9.50)\end{array}$ \\
\hline Educ & $\begin{array}{l}-0.046^{* * *} \\
(-6.79)\end{array}$ & $\begin{array}{l}0.129^{* * *} \\
(16.80)\end{array}$ & $\begin{array}{l}-0.035^{* * *} \\
(-5.17)\end{array}$ \\
\hline Party & $\begin{array}{l}0.159 * * \\
(2.29)\end{array}$ & $\begin{array}{l}-0.121 * \\
(-1.74)\end{array}$ & $\begin{array}{l}0.155^{* *} \\
(2.22)\end{array}$ \\
\hline$J o b$ & $\begin{array}{l}-0.146^{* * *} \\
(-7.83)\end{array}$ & $\begin{array}{l}0.162 * * * \\
(8.67)\end{array}$ & $\begin{array}{l}-0.133^{* * *} \\
(-7.06)\end{array}$ \\
\hline Urban & $\begin{array}{l}-0.307^{* * *} \\
(-15.58)\end{array}$ & $\begin{array}{l}0.234^{* * *} \\
(11.77)\end{array}$ & $\begin{array}{l}-0.291 \\
(-14.61)\end{array}$ \\
\hline Income & $\begin{array}{l}0.075^{* * *} \\
(6.83)\end{array}$ & $\begin{array}{l}0.032^{* * *} \\
(2.95)\end{array}$ & $\begin{array}{l}0.080^{* * * *} \\
(7.19)\end{array}$ \\
\hline Status & $\begin{array}{l}0.245^{* * *} \\
(21.50)\end{array}$ & $\begin{array}{l}0.006 \\
(0.53)\end{array}$ & $\begin{array}{l}0.244^{* * *} \\
(21.22)\end{array}$ \\
\hline Organization & $\begin{array}{l}0.192^{* * *} \\
(7.37)\end{array}$ & $\begin{array}{l}0.177^{* * *} \\
(6.63)\end{array}$ & $\begin{array}{l}0.203^{* * * *} \\
(7.80)\end{array}$ \\
\hline Conflict & $\begin{array}{l}-0.450 * * * \\
(-36.56)\end{array}$ & $\begin{array}{l}0.179^{* * *} \\
(14.59)\end{array}$ & $\begin{array}{l}-0.439 \\
(-35.29)\end{array}$ \\
\hline LogperGDP & $\begin{array}{l}0.203 \\
(0.52)\end{array}$ & $\begin{array}{l}-1.866^{* * *} \\
(-4.90)\end{array}$ & $\begin{array}{l}0.135 \\
(0.34)\end{array}$ \\
\hline Density & $\begin{array}{l}5.556 \\
(0.55)\end{array}$ & $\begin{array}{l}24.982 * * \\
(2.47)\end{array}$ & $\begin{array}{l}6.126 \\
(0.60)\end{array}$ \\
\hline Density2 & $\begin{array}{l}-0.346 \\
(-0.54)\end{array}$ & $\begin{array}{l}-1.588^{* *} \\
(-2.52)\end{array}$ & $\begin{array}{l}-0.381 \\
(-0.60)\end{array}$ \\
\hline Mindex & $\begin{array}{l}0.011 \\
(0.24)\end{array}$ & $\begin{array}{l}0.131 * * * \\
(2.80)\end{array}$ & $\begin{array}{l}0.015 \\
(0.31)\end{array}$ \\
\hline Yeardummy & Yes & Yes & Yes \\
\hline Regiondummy & Yes & Yes & Yes \\
\hline$N$ & 42,056 & 41,449 & 41,449 \\
\hline
\end{tabular}

a T-statistics are reported in parentheses; $t$-values are calculated based on robust standard errors. ${ }^{\mathrm{b}}$ Significance at the $1 \%$ level is denoted as ${ }^{* * *}, 5 \%$ level as ${ }^{* *}$, and $10 \%$ level as *. ${ }^{c}$ Please refer to Appendix B for the detailed definitions of variables.

Table 10. Tests of mediation effects.

\begin{tabular}{lllll}
\hline & Coefficient & Std Error & Z-Value & $p$-Value \\
\hline Sobel statistics & -0.0002 & 0.00007 & -3.307 & 0.0009 \\
Goodman I statistics & -0.0002 & 0.00007 & -3.3 & 0.001 \\
Goodman II statistics & -0.0002 & 0.00007 & -3.314 & 0.0009 \\
\hline
\end{tabular}

\subsection{Cross-Sectional Analyses on Individual Characteristics}

To obtain more insight into the effects of environmental pollution disasters on citizens' political trust, we also investigate whether this relationship varies based on a series of individual characteristics. Numerous studies have emphasized the effects of individual characteristics on citizens' political behaviors. For example, Inglehart and Norris (2003) [90] indicated that there are significant differences 
in the political attitudes, voting behavior and political trust between women and men. Catterberg and Moreno (2006) [65] found that education has no effect on political trust in Eastern Europe, but it is negatively related to political trust in former Soviet republics and Latin America. Hence, we infer that the relationship between environmental pollution disasters and political trust could be different for individuals with different characteristics.

In this subsection, we focus on the possible moderating effects of gender, age, education level, income level, and political identity. Disasters ${ }^{*}$ Gender, Disasters ${ }^{*}$ Logage, Disasters ${ }^{*} E d u c$, Disasters*Income, and Disasters*Party are incorporated into the regressions. The regression results are reported in Table 11. We can see that all interaction terms are statistically insignificant except for Disasters ${ }^{*} G e n d e r$ and Disasters*Party. We can see that political trust of women is less likely to be affected by the environmental pollution disasters, which is consistent with the finding that men appear to be more distrustful of government than women [63]. As for the positive moderating effect of party membership, it also makes sense. In China, most citizens consider party and government in conjunction. For citizens who are party members, the education they received from the party and their original political attitudes would strongly support their confidence and trust of the government.

Table 11. Moderating effects of individual characteristics ${ }^{a, b, c}$.

\begin{tabular}{|c|c|c|c|c|c|}
\hline & (1) & (2) & (3) & (4) & (5) \\
\hline $\begin{array}{l}\text { Disasters } \\
\text { Disasters }{ }^{*} \text { Gender }\end{array}$ & $\begin{array}{l}-0.001 * \\
(-1.70) \\
-0.001 \text { ** } \\
(-2.12)\end{array}$ & $\begin{array}{l}-0.002 \text { ** } \\
(-2.26)\end{array}$ & $\begin{array}{l}-0.001 * \\
(-1.82)\end{array}$ & $\begin{array}{l}-0.002^{* * *} \\
(-2.63)\end{array}$ & $\begin{array}{l}-0.002^{* *} \\
(-2.31)\end{array}$ \\
\hline Disasters ${ }^{*}$ Logage & & $\begin{array}{l}0.000 \\
(0.57)\end{array}$ & & & \\
\hline Disasters ${ }^{*}$ Educ & & & $\begin{array}{l}-0.000 \\
(-1.47)\end{array}$ & & \\
\hline Disasters*Income & & & & $\begin{array}{l}0.000 \\
(1.31)\end{array}$ & \\
\hline Disasters ${ }^{*}$ Party & & & & & $\begin{array}{l}0.003 * \\
(1.72)\end{array}$ \\
\hline Gender & $\begin{array}{l}-0.039 * \\
(-1.95)\end{array}$ & $\begin{array}{l}-0.056^{* * *} \\
(-3.15)\end{array}$ & $\begin{array}{l}-0.057^{* * *} \\
(-3.20)\end{array}$ & $\begin{array}{l}-0.056^{* * * *} \\
(-3.15)\end{array}$ & $\begin{array}{l}-0.056^{* * *} \\
(-3.13)\end{array}$ \\
\hline Logage & $\begin{array}{l}-4.553^{* * *} \\
(-9.06)\end{array}$ & $\begin{array}{l}-4.522^{* * *} \\
(-8.92)\end{array}$ & $\begin{array}{l}-4.545^{* * *} \\
(-9.04)\end{array}$ & $\begin{array}{l}-4.542^{* * *} \\
(-9.04)\end{array}$ & $\begin{array}{l}-4.551^{\text {**** }} \\
(-9.06)\end{array}$ \\
\hline Logage2 & $\begin{array}{l}0.695^{* * *} \\
(10.18)\end{array}$ & $\begin{array}{l}0.690^{* * *} \\
(9.99)\end{array}$ & $\begin{array}{l}0.694^{* * *} \\
(10.16)\end{array}$ & $\begin{array}{l}0.694^{* * *} \\
(10.16)\end{array}$ & $\begin{array}{l}0.695^{* * *} \\
(10.18)\end{array}$ \\
\hline Educ & $\begin{array}{l}-0.046^{* * *} \\
(-6.83)\end{array}$ & $\begin{array}{l}-0.046^{* * *} \\
(-6.77)\end{array}$ & $\begin{array}{l}-0.041^{* * *} \\
(-5.56)\end{array}$ & $\begin{array}{l}-0.046^{* * *} \\
(-6.82)\end{array}$ & $\begin{array}{l}-0.046^{\text {**** }} \\
(-6.80)\end{array}$ \\
\hline Party & $\begin{array}{l}0.158^{* *} \\
(2.26)\end{array}$ & $\begin{array}{l}0.159^{* *} \\
(2.28)\end{array}$ & $\begin{array}{l}0.158^{* *} \\
(2.27)\end{array}$ & $\begin{array}{l}0.160 \text { ** } \\
(2.30)\end{array}$ & $\begin{array}{l}0.102 * \\
(1.72)\end{array}$ \\
\hline$J o b$ & $\begin{array}{l}-0.146^{* * *} \\
(-7.84)\end{array}$ & $\begin{array}{l}-0.146^{* * *} \\
(-7.85)\end{array}$ & $\begin{array}{l}-0.146^{* * *} \\
(-7.86)\end{array}$ & $\begin{array}{l}-0.146^{* * *} \\
(-7.85)\end{array}$ & $\begin{array}{l}-0.145^{* * *} \\
(-7.82)\end{array}$ \\
\hline Urban & $\begin{array}{l}-0.307^{* * *} \\
(-15.57)\end{array}$ & $\begin{array}{l}-0.307 * * * \\
(-15.59)\end{array}$ & $\begin{array}{l}-0.308^{* * *} \\
(-15.64)\end{array}$ & $\begin{array}{l}-0.307^{* * *} \\
(-15.58)\end{array}$ & $\begin{array}{l}-0.307^{* * *} \\
(-15.58)\end{array}$ \\
\hline Income & $\begin{array}{l}0.075^{* * *} \\
(6.84)\end{array}$ & $\begin{array}{l}0.075^{* * *} \\
(6.82)\end{array}$ & $\begin{array}{l}0.075^{* * *} \\
(6.83)\end{array}$ & $\begin{array}{l}0.070 * * * \\
(5.78)\end{array}$ & $\begin{array}{l}0.075^{* * *} \\
(6.83)\end{array}$ \\
\hline Status & $\begin{array}{l}0.245^{* * *} \\
(21.50)\end{array}$ & $\begin{array}{l}0.245^{* * *} \\
(21.50)\end{array}$ & $\begin{array}{l}0.245^{* * *} \\
(21.50)\end{array}$ & $\begin{array}{l}0.245^{* * *} \\
(21.50)\end{array}$ & $\begin{array}{l}0.245^{* * * *} \\
(21.50)\end{array}$ \\
\hline Organization & $\begin{array}{l}0.192 * * * * \\
(7.38)\end{array}$ & $\begin{array}{l}0.192 * * * \\
(7.38)\end{array}$ & $\begin{array}{l}0.192 * * * \\
(7.37)\end{array}$ & $\begin{array}{l}0.1911^{* * * *} \\
(7.35)\end{array}$ & $\begin{array}{l}0.192 * * * \\
(7.38)\end{array}$ \\
\hline Conflict & $\begin{array}{l}-0.450 * * * \\
(-36.57)\end{array}$ & $\begin{array}{l}-0.450 * * * \\
(-36.56)\end{array}$ & $\begin{array}{l}-0.450 * * * \\
(-36.57)\end{array}$ & $\begin{array}{l}-0.449^{* * *} \\
(-36.54)\end{array}$ & $\begin{array}{l}-0.450 * * * \\
(-36.55)\end{array}$ \\
\hline
\end{tabular}


Table 11. Cont.

\begin{tabular}{llllll}
\hline & $\mathbf{( 1 )}$ & $\mathbf{( 2 )}$ & $\mathbf{( 3 )}$ & $\mathbf{( 4 )}$ & $\mathbf{( 5 )}$ \\
\hline \multirow{2}{*}{ LogperGDP } & 0.191 & 0.188 & 0.164 & 0.237 & 0.184 \\
& $(0.49)$ & $(0.48)$ & $(0.42)$ & $(0.61)$ & $(0.47)$ \\
Density & 6.423 & 6.363 & 6.335 & 6.261 & 6.344 \\
& $(0.67)$ & $(0.67)$ & $(0.67)$ & $(0.66)$ & $(0.67)$ \\
Density2 & -0.399 & -0.395 & -0.394 & -0.389 & -0.394 \\
& $(-0.67)$ & $(-0.66)$ & $(-0.66)$ & $(-0.65)$ & $(-0.66)$ \\
Mindex & 0.010 & 0.010 & 0.007 & 0.013 & 0.010 \\
Yeardummy & $(0.20)$ & $(0.20)$ & $(0.15)$ & $(0.27)$ & $(0.21)$ \\
Regiondummy & Yes & Yes & Yes & Yes & Yes \\
$N$ & Yes & Yes & Yes & Yes & Yes \\
\hline
\end{tabular}

${ }^{a}$ T-statistics are reported in parentheses; $t$-values are calculated based on robust standard errors. ${ }^{\mathrm{b}}$ Significance at the $1 \%$ level is denoted as ${ }^{* * *}, 5 \%$ level as ${ }^{* *}$, and $10 \%$ level as *. ${ }^{\mathrm{c}}$ Please refer to Appendix B for the detailed definitions of variables.

\subsection{Do the Positive Activities of Government Help?}

After confirming the relationship between environmental pollution disasters and citizens' political trust, we still have a question: Are there effective tactics that can be adopted by the government to cope with negative effects of these emergent environmental events? In fact, the occurrences of most emergent environmental events are more or less associated with objective reasons and contingency. However, when disasters have happened, the responsive manner of the government may be more important to people. Edelstein (1988) [91] indicated that government's poor performance in taking prompt remediation efforts in dealing with hazardous waste sites resulted in loss of citizens' trust to a great extent. Therefore, we predict that government's positive attitudes and efforts in resolving environmental problems may partially mitigate citizens' sense of distrust induced by environmental pollution disasters.

Specifically, we investigate government's positive activities from two perspectives: activities in communicating with citizens, and activities in resolving environmental pollution problems. First, more communication can help to mitigate the information asymmetry between government and citizens, which further benefits reaching an understanding. Previous literature also indicates that people tend to trust governments who deliver services in a transparent manner [92,93]. Second, practical actions are more persuasive for people to trust the government's responsiveness and effectiveness. Hearing is measured as the number of times of public hearing hosted by the government on the main topic of environmental issues. Investment is measured as the logarithm of the amount of money government invested in resolving environmental problems. These two variables serve as proxies for the government's activities in communicating with citizens and resolving environmental pollution problems, respectively. Data were hand-collected from the China Environment Yearbook issued by the Ministry of Environmental Protection. To test our prediction, Hearing, Investment, and their interaction terms with Disasters are included in regressions. The empirical results are shown in Table 12. We can see that coefficients of the interaction terms are both positive and significant, which confirms our prediction. 
Table 12. The moderating effects of government's behaviors ${ }^{a, b, c}$.

\begin{tabular}{|c|c|c|}
\hline & (1) & (2) \\
\hline Disasters & $\begin{array}{l}-0.005^{* * *} \\
(-2.83)\end{array}$ & $\begin{array}{l}-0.003^{* *} \\
(-2.11)\end{array}$ \\
\hline Disasters ${ }^{*}$ Hearing & $\begin{array}{l}0.001 * \\
(1.84)\end{array}$ & \\
\hline Hearing & $\begin{array}{l}-0.005 \\
(-1.30)\end{array}$ & \\
\hline Disasters ${ }^{*}$ Investment & & $\begin{array}{l}0.002 * \\
(1.85)\end{array}$ \\
\hline Investment & & $\begin{array}{l}0.063 \\
(1.12)\end{array}$ \\
\hline Gender & $\begin{array}{l}-0.100^{* * *} \\
(-4.12)\end{array}$ & $\begin{array}{l}-0.056^{\text {*** }} \\
(-3.12)\end{array}$ \\
\hline Logage & $\begin{array}{l}-6.275^{* * *} \\
(-9.16)\end{array}$ & $\begin{array}{l}-4.544^{* * *} \\
(-9.04)\end{array}$ \\
\hline Logage2 & $\begin{array}{l}0.960^{* * *} \\
(10.32)\end{array}$ & $\begin{array}{l}0.694^{* * *} \\
(10.16)\end{array}$ \\
\hline Educ & $\begin{array}{l}-0.071^{* * *} \\
(-7.59)\end{array}$ & $\begin{array}{l}-0.046^{* * *} \\
(-6.80)\end{array}$ \\
\hline Party & $\begin{array}{l}0.239 * * \\
(2.53)\end{array}$ & $\begin{array}{l}0.160 * * \\
(2.29)\end{array}$ \\
\hline$J o b$ & $\begin{array}{l}-0.203^{* * *} \\
(-7.96)\end{array}$ & $\begin{array}{l}-0.145^{\text {*** }} \\
(-7.80)\end{array}$ \\
\hline Urban & $\begin{array}{l}-0.421^{* * *} \\
(-15.64)\end{array}$ & $\begin{array}{l}-0.307^{\text {*** }} \\
(-15.59)\end{array}$ \\
\hline Income & $\begin{array}{l}0.100^{* * *} \\
(6.82)\end{array}$ & $\begin{array}{l}0.075^{* * *} \\
(6.84)\end{array}$ \\
\hline Status & $\begin{array}{l}0.315^{* * *} \\
(21.21)\end{array}$ & $\begin{array}{l}0.245^{* * *} \\
(21.48)\end{array}$ \\
\hline Organization & $\begin{array}{l}0.264^{* * * *} \\
(7.44)\end{array}$ & $\begin{array}{l}0.192^{* * * *} \\
(7.39)\end{array}$ \\
\hline Conflict & $\begin{array}{l}-0.615^{* * *} \\
(-37.66)\end{array}$ & $\begin{array}{l}-0.450 * * * \\
(-36.55)\end{array}$ \\
\hline LogperGDP & $\begin{array}{l}0.491 \\
(0.84)\end{array}$ & $\begin{array}{l}0.188 \\
(0.44)\end{array}$ \\
\hline Density & $\begin{array}{l}11.886 \\
(0.84)\end{array}$ & $\begin{array}{l}5.372 \\
(0.53)\end{array}$ \\
\hline Density2 & $\begin{array}{l}-0.734 \\
(-0.83)\end{array}$ & $\begin{array}{l}-0.332 \\
(-0.52)\end{array}$ \\
\hline Mindex & $\begin{array}{l}0.023 \\
(0.33)\end{array}$ & $\begin{array}{l}0.014 \\
(0.27)\end{array}$ \\
\hline Yeardummy & Yes & Yes \\
\hline Regiondummy & Yes & Yes \\
\hline$N$ & 42,056 & 42,056 \\
\hline
\end{tabular}

a T-statistics are reported in parentheses; $t$-values are calculated based on robust standard errors. ${ }^{\mathrm{b}}$ Significance at the $1 \%$ level is denoted as ***, $5 \%$ level as ${ }^{* *}$, and $10 \%$ level as *. ${ }^{\text {c }}$ Please refer Appendix B for the detail definitions of variables.

\section{Discussion and Conclusions}

This research indicates that the occurrence of environmental pollution disasters is negatively related to citizens' political trust. This result still holds after controlling for endogeneity issues and a series of robustness tests. In the analysis of possible mechanisms, we find that increasing of citizens' environmental awareness is a significant mediation. Possible moderating effects of demographical variables are also tested. Male citizens and non-party member citizens are more responsive to environmental pollution disasters. With these conclusions, the environmental problems not only harm people's health but also threaten sustainability and competency of the political system. 
Therefore, environmental protection should not only be health or social issues, but also be an important political topic. This finding can be applied by policy-makers worldwide for promoting environmental protection policies.

In addition, this study further finds the negative relationship between environmental pollution disasters and political trust is less pronounced when government communicate more with citizens about environmental issues or invest more money in governing pollution. Given the results, the positive attitudes and efforts in resolving problems may partially restore citizens' trust following the occurrence of environmental pollution disasters. Therefore, when environmental pollution disasters have happened, this finding provides some efficient ways to reduce the negative effect of emergent environmental events on government reputation.

Similar to all empirical studies, this study has some limitations. First, we do not differentiate various types of environmental pollution disasters. The Ministry of Environmental Protection discloses the statistics on the occurrence of environmental pollution disasters on its website (www.zhb.gov.cn) every year. However, only some severe cases are simultaneously disclosed in detail, and the specific information of most emergent environmental events is missing. The inaccessibility of data deters our further investigation from this perspective. Second, there still are deficiencies in the measurement of political trust. As we mentioned before, we cannot directly evaluate the citizens' trust of central government or the whole political institution. In addition, trust is also a multi-dimensional terminology, which includes at least three dimensions-ability, benevolence, and integrity. As a national survey, CFPS can hardly cover all these aspects. We greatly encourage and appreciate following studies to fix these deficiencies.

Acknowledgments: This work was supported by the Innovative Group Project of the National Natural Science Foundation of China (Grant No. 71221001) and the Ph.D. Programs Foundation of the Ministry of Education of China (Grant No. 20130161110045).

Author Contributions: All authors discussed and agreed on the ideas and scientific contributions. Min Zhang collected and cleaned the data; Shenggang Yang and Xun Gong performed the empirical tests; Xun Gong and Min Zhang wrote the paper, and Shenggang Yang contributed to the refinement of the manuscript.

Conflicts of Interest: The authors declare no conflict of interest.

\section{Appendix A}

Table A1. Assessment Criteria of Emergent Environmental Events.

\begin{tabular}{ll}
\hline Emergent Events Level & Assessment Criterias \\
\hline At least one of the following criteria is met: \\
1. $\quad \begin{array}{l}\text { Directly lead to more than } 30 \text { deaths, or more than } 100 \text { poisoned or } \\
\text { seriously injured. } \\
\text { Directly lead to more than } 50 \text { thousands persons mandatorily transferred } \\
\text { or evacuated. } \\
\text { Directly lead to more than } 100 \text { million economic losses. } \\
\text { (Level I events) }\end{array}$ \\
3. $\quad \begin{array}{l}\text { Directly lead to complete loss of regional ecological functions, or lead } \\
\text { toregional extinction of national key protected species. }\end{array}$ \\
5. $\quad \begin{array}{l}\text { Directly lead to serious pollution of city level centralized drinking } \\
\text { water sources. } \\
\text { The incidents of I or II class radioactive sources lost or leaked, and further } \\
\text { cause large-scale serious radiation contamination. The incidents of } \\
\text { radioactive facilities leak, which lead to more than } 3 \text { persons dying } \\
\text { acutely. The incidents of leakage of radioactive materials, and further } \\
\text { cause large-scale serious radiation contamination. } \\
\text { Directly lead to serious cross-border environmental influences. }\end{array}$ \\
7.
\end{tabular}


Table A1. Cont.

\begin{tabular}{|c|c|}
\hline Emergent Events Level & Assessment Criterias \\
\hline \multirow{8}{*}{$\begin{array}{l}\text { Severe events } \\
\text { (Level II events) }\end{array}$} & At least one of the following criteria is met: \\
\hline & $\begin{array}{l}\text { 1. Directly lead to more than } 10 \text { but less than } 30 \text { deaths, or more than } 50 \text { but } \\
\text { less than } 100 \text { poisoned or seriously injured. }\end{array}$ \\
\hline & $\begin{array}{l}\text { 2. Directly lead to more than } 10 \text { but less than } 50 \text { thousand persons } \\
\text { mandatorily transferred or evacuated. }\end{array}$ \\
\hline & 3. Directly lead to more than 20 but less than 100 million economic losses. \\
\hline & $\begin{array}{l}\text { 4. Directly lead to partial loss of regional ecological functions, or lead to } \\
\text { regional massive mortality of national key protected species. }\end{array}$ \\
\hline & $\begin{array}{l}\text { 5. Directly lead to serious pollution of county level centralized drinking } \\
\text { water sources. }\end{array}$ \\
\hline & $\begin{array}{l}\text { 6. The incidents of I or II class radioactive sources lost or leaked. The } \\
\text { incidents of radioactive facilities leak, which lead to less than } 3 \text { persons } \\
\text { dying acutely or more than } 10 \text { persons infected with acute severe } \\
\text { radiation sickness. The incidents of leakage of radioactive materials, and } \\
\text { further cause of relatively large-scale serious radiation contamination. }\end{array}$ \\
\hline & 7. Lead to emergent cross-province environmental influences. \\
\hline \multicolumn{2}{|r|}{ At least one of the following criteria is met: } \\
\hline \multirow{7}{*}{$\begin{array}{l}\text { Large events } \\
\text { (Level III events) }\end{array}$} & $\begin{array}{l}\text { 1. Directly lead to more than } 3 \text { but less than } 10 \text { deaths, or more than } 10 \text { but } \\
\text { less than } 50 \text { poisoned or seriously injured. }\end{array}$ \\
\hline & $\begin{array}{l}\text { 2. Directly lead to more than } 5 \text { but less than } 10 \text { thousand persons } \\
\text { mandatorily transferred or evacuated. }\end{array}$ \\
\hline & Directly lead to more than 5 but less than 20 millions economic losses. \\
\hline & Directly lead to material destruction of national key protected species. \\
\hline & $\begin{array}{l}\text { Directly lead to serious pollution of village or town level centralized } \\
\text { drinking water sources. }\end{array}$ \\
\hline & $\begin{array}{l}\text { The incidents of III radioactive sources lost or leaked. The incidents of } \\
\text { radioactive facilities leak, which lead to less than } 10 \text { persons infected } \\
\text { acutely with severe radiation sickness. The incidents of leakage of } \\
\text { radioactive materials, and further cause small-scale serious } \\
\text { radiation contamination. }\end{array}$ \\
\hline & 7. Lead to emergent cross-city environmental influences. \\
\hline
\end{tabular}

At least one of the following criteria is met:

1. Directly lead to less than 3 deaths, or less than 10 poisoned or seriously injured.

2. Directly lead to less than 5 thousands persons mandatorily transferred or evacuated.

General events (Level IV events)

3. Directly lead to less than 5 millions economic losses.

4. Lead to cross-county environmental influences.

5. The incidents of IV or V class radioactive sources lost or leaked. The incidents of radioactive facilities leak, which expose people to radiation overload. The incidents of leakage of radioactive materials, and further cause of low radiation contamination.

6. Cause a certain degree of environmental influence but do not exhibitthe criteria of Level III events. 


\section{Appendix B}

Table A2. Variable Definitions.

\begin{tabular}{|c|c|}
\hline Variables & Definitions \\
\hline Trust & $\begin{array}{l}\text { Citizen's political trust. Measured as the rating of citizen's trust in local government officials, } \\
\text { which ranges from } 0 \text { to } 10 .\end{array}$ \\
\hline Disasters & $\begin{array}{l}\text { The occurrence and severity of environmental pollution disasters, measured based on statistics of } \\
\text { emergent environmental events. The specific model is Disasters }=2 * \text { \# of Level II events }+1.5^{*} \text { \# of } \\
\text { Level III events + \# of Level IV events. }\end{array}$ \\
\hline Gender & $\begin{array}{l}\text { A dummy variable indicates the gender of the respondent. Equals one if the person is male, } \\
\text { and zero otherwise. }\end{array}$ \\
\hline Logage & Logarithm of individual's age. \\
\hline Logage2 & The square term of Logage. \\
\hline Educ & $\begin{array}{l}\text { An ordered variable measures the individual's education level, which ranges from zero to eight. } \\
\text { Equals zero, indicates never being educated; equals one, indicates less than primary school level } \\
\text { education; equals two, indicates graduated from primary school; equals three, indicates graduated } \\
\text { from junior high school; equals four, indicates graduated from high school; equals five, indicates } \\
\text { graduated from junior college; equals six, indicates a bacholar degree; equals seven indicates } \\
\text { amaster's degree; equals eight, indicates a Ph.D. degree. }\end{array}$ \\
\hline Party & A dummy variable indicates whether the respondent is a communist party member. \\
\hline Job & Equals one if the citizen is engaged in non-agricultural work, and zero otherwise. \\
\hline Urban & Equals one if the individual lives in a city, and zero otherwise. \\
\hline Income & $\begin{array}{l}\text { An ordered variable measued as citizen's self-evaluation of his/her income in local place; } \\
\text { this variable ranges from one to five, one means the lowest incoem level, five means the highest } \\
\text { income level. }\end{array}$ \\
\hline Status & $\begin{array}{l}\text { An ordered variable measued as citizen's self-evaluation of his/her social status in local place; } \\
\text { this variable ranges from one to five, one meansthe lowest social class, five means the highest } \\
\text { social class. }\end{array}$ \\
\hline Organization & A dummy variable indicates whether the respondent joins any association or organization. \\
\hline Conflict & $\begin{array}{l}\text { An ordered variable that measures individual's adverse experiences in getting along with local } \\
\text { government. It equals two if the individual personally used to have conflict with government; } \\
\text { it equals one if the individual heard or observed others were unfairly treated by government; } \\
\text { it equals zero otherwise. }\end{array}$ \\
\hline PerGDP & The GDP per person in the province where the respondent lives. \\
\hline LogperGDP & The logarithm of PerGDP. \\
\hline Density & The logarithm of the polulation per suqare kilometer. \\
\hline Density2 & The square term of Density. \\
\hline Mindex & $\begin{array}{l}\text { The marketization index issued by Fan et al. (2011) [61]. The higher the value of Market, the faster } \\
\text { the process of regional marketization and the better the regional institutional environment. }\end{array}$ \\
\hline Corruption & The number of legal cases on government officials' corruption and misconducts \\
\hline Socialtrust & Following Wu et al. (2014) [78], it is measured as the voluntary blood donation rates. \\
\hline Religion & $\begin{array}{l}\text { Proportion of religious members in the provincial-level Chinese People's Political } \\
\text { Consultative Conference. }\end{array}$ \\
\hline Confucianism & $\begin{array}{l}\text { Following Du (2014) [83], Confucianism equals one if the citizen lives in Shandong, Henan, Sichuan, } \\
\text { Fujian, Jiangsu, Zhejiang, or Jiangxi province, and zero otherwise. }\end{array}$ \\
\hline Awareness & $\begin{array}{l}\text { Citizen's perception of the importance of environmental protection. It is measured based on the } \\
\text { question asked in CFPS. }\end{array}$ \\
\hline Hearing & Times of public hearings hosted by the government on the main topic of environmental issues. \\
\hline Investment & $\begin{array}{l}\text { The logarithm of the amount of money government invested in resolving } \\
\text { environmental problems. }\end{array}$ \\
\hline
\end{tabular}




\section{References}

1. Golley, J.; Zheng, W. Population dynamics and economic growth in China. China. Econ. Rev. 2015, 35, 15-32. [CrossRef]

2. Jiang, L.; Hiltunen, E.; He, X.; Zhu, L. A Questionnaire Case Study to Investigate Public Awareness of Smog Pollution in China's Rural Areas. Sustainability. 2016, 8, 1111-1121. [CrossRef]

3. Chan, C.K.; Yao, X. Air pollution in mega cities in China. Atmos. Environ. 2008, 42, 1-42. [CrossRef]

4. Liu, J.; Diamond, J. China's environment in a globalizing world. Nature 2005, 435, 1179-1186. [CrossRef] [PubMed]

5. Brender, J.D.; Maantay, J.A.; Chakraborty, J. Residential proximity to environmental hazards and adverse health outcomes. AM. J. Public. Health. 2011, 101 (S1), S37-S52. [CrossRef] [PubMed]

6. Zhang, J.; Mauzerall, D.L.; Zhu, T.; Liang, S.; Ezzati, M.; Remais, J.V. Environmental health in China: progress towards clean air and safe water. The lancet 2010, 375, 1110-1119. [CrossRef]

7. The World Bank. China: Air, Land, and Water: Environmental Priorities for a New Millennium. 2001. Available online: http:/ / siteresources.worldbank.org/INTEAPREGTOPENVIRONMENT/Resources / china-environment1.pdf (accessed on 4 February 2017).

8. Chen, Y.; Ebenstein, A.; Greenstone, M.; Li, H. Evidence on the impact of sustained exposure to air pollution on life expectancy from China's Huai River policy. P. Natl. A. Sci. 2013, 110, 12936-12941. [CrossRef] [PubMed]

9. Chen, J. Rapid urbanization in China: a real challenge to soil protection and food security. Catena 2007, 69, 1-15. [CrossRef]

10. Khan, S.; Cao, Q.; Zheng, Y.M.; Huang, Y.Z.; Zhu, Y.G. Health risks of heavy metals in contaminated soils and food crops irrigated with wastewater in Beijing, China. Environ. Pollut. 2008, 152, 686-692. [CrossRef] [PubMed]

11. Calderón-Garcidueñas, L.; Calderón-Garcidueñas, A.; Torres-Jardón, R.; Avila-Ramírez, J.; Kulesza, R.J.; Angiulli, A.D. Air pollution and your brain: what do you need to know right now. Prim. Health. Care. Res. 2015, 16, 329-345. [CrossRef] [PubMed]

12. Clougherty, J.E.; Levy, J.I.; Kubzansky, L.D.; Ryan, P.B.; Suglia, S.F.; Canner, M.J.; Wright, R.J. Synergistic effects of traffic-related air pollution and exposure to violence on urban asthma etiology. Environ. Health. Pers. 2007, 115, 1140-1146. [CrossRef] [PubMed]

13. Granieri, A. Community exposure to asbestos in Casale Monferrato: from research on psychological impact to a community needs-centered healthcare organization. Annali dell'Istituto Superiore di Sanità. 2015, 51, 336-341. [PubMed]

14. Newton, K.; Norris, P. "Confidence in Public Institutions: Faith, Culture or Performance?" in Disaffected democracies: What's Troubling the Trilateral Countries; Princeton University Press: Princeton, NJ, USA, 1999.

15. Wang, Z. Before the emergence of critical citizens: Economic development and political trust in China. Int. Rev. Sociol. 2005, 15, 155-171. [CrossRef]

16. Miller, A.H.; Listhaug, O. Political parties and confidence in government: A comparison of Norway, Sweden and the United States. Brit. J. Polit. Sci. 1990, 20, 357-386. [CrossRef]

17. Hetherington, M.J. Why Trust Matters: Declining Political Trust and the Demise of American Liberalism; Princeton University Press: Princeton, NJ, USA, 2005.

18. Blind, P.K. Building trust in government in the twenty-first century: Review of literature and emerging issues. In Proceeding of 7th Global Forum on Reinventing Government Building Trust in Government, Vienna, Austria, 26-29 June 2007; Available online: http:/ / unpan1.un.org/intradoc/groups/public/documents / UN/UNPAN025062.pdf (accessed on 4 February 2017).

19. Lewicki, R.J.; Tomlinson, E.C. Trust and trust building. Beyond Intractabil. 2003, pp. 305-315. Available online: http:/ / www.beyondintractability.org/essay/trust-building (accessed on 4 February 2017).

20. Levitsky, S.; Way, L. The rise of competitive authoritarianism. J. Demor. 2002, 13, 51-65. [CrossRef]

21. Zhong, Y. Do Chinese people trust their local government, and why? An empirical study of political trust in urban China. Probl. Post-Communism. 2014, 61, 31-44. [CrossRef]

22. Gabriel, A.; Verba, S. The Civic Culture: Political Attitudes and Democracy in Five Nations; SAGE Publications, Inc.: Thousand Oaks, USA, 1963; pp. 136-185.

23. Coleman, J.S. Foundations of Social Theory; Harvard University Press: Cambridge, USA, 1994. 
24. Hetherington, M.J. The political relevance of political trust. Am. Political Sci. Rev. 1998, 92, 791-808. [CrossRef]

25. Mishler, W.; Rose, R. What are the origins of political trust? Testing institutional and cultural theories in post-communist societies. Comp. Political Stud. 2001, 34, 30-62. [CrossRef]

26. Christensen, T.; Lægreid, P. Trust in government: The relative importance of service satisfaction, political factors, and demography. Public Perform. Manag. 2005, 28, 487-511.

27. Williams, J.T. Systemic influences on political trust: The importance of perceived institutional performance. Political Methodol. 1985, 11, 125-142.

28. Dalton, R.J. The social transformation of trust in government. Int. Rev. Sociol. 2005, 15, 133-154. [CrossRef]

29. Dalton, R.J.; Wattenberg, M.P. Parties without Partisans: Political Change in Advanced Industrial Democracies; Oxford University Press: Oxford, UK, 2002.

30. Wang, Z.; You, Y. The arrival of critical citizens: Decline of political trust and shifting public priorities in China. Int. Rev. Sociol. 2016, 26, 105-124. [CrossRef]

31. David, T. The public trust doctrine, environmental human rights, and the future of private property. N. $Y$. Univ. Environ. Law J. 2008, 16, 711-765.

32. Guglielmucci, F.; Franzoi, I.G.; Zuffranieri, M.; Granieri, A. Living in contaminated sites: Which cost for psychic health? Mediterr. J. Soc. Sci. 2015, 6, 207. [CrossRef]

33. Guglielmucci, F.; Franzoi, I.G.; Barbasio, C.P.; Borgogno, F.V.; Granieri, A. Helping traumatized people survive: A psychoanalytic intervention in a contaminated site. Front. Psychol. 2014, 5, 1419. [CrossRef] [PubMed]

34. Davis, D.L. A look back at the London smog of 1952 and the half century since. Environ. Health Perspect. 2002, 110, A734. [CrossRef] [PubMed]

35. Foster, V.; Hahn, R.W. Designing more efficient markets: Lessons from Los Angeles smog control. J. Law Econ. 1995, 38, 19-48. [CrossRef]

36. Tsuda, T.; Yorifuji, T.; Takao, S.; Miyai, M.; Babazono, A. Minamata disease: Catastrophic poisoning due to a failed public health response. J. Public Health Policy 2009, 30, 54-67. [CrossRef] [PubMed]

37. Zhu, L.; Hiltunen, E.; Antila, E.; Huang, F.; Song, L. Investigation of China's bio-energy industry development modes based on a SWOT-PEST model. Int. J. Sustain. Energy. 2015, 34, 552-559. [CrossRef]

38. Ge, Y.; Zhang, H.; Dou, W.; Chen, W.; Liu, N.; Wang, Y.; Shi, Y.; Rao, W. Mapping Social Vulnerability to Air Pollution: A Case Study of the Yangtze River Delta Region, China. Sustainability 2017, 9, 109. [CrossRef]

39. Lo, K. A critical review of China's rapidly developing renewable energy and energy efficiency policies. Renew. Sustain. Energy Rev. 2014, 29, 508-516. [CrossRef]

40. Hugo, G. Environmental concerns and international migration. Int. Migr. Rev. 1996, 30, 105-131. [CrossRef] [PubMed]

41. Sims, C.A. Implications of rational inattention. J. Monet. Econ. 2003, 50, 665-690. [CrossRef]

42. Srinivas, H.; Nakagawa, Y. Environmental implications for disaster preparedness: Lessons learnt from the Indian Ocean Tsunami. J. Environ. Manag. 2008, 89, 4-13. [CrossRef] [PubMed]

43. Chen, Y.; Yang, D.Y. Historical Traumas and the Roots of Political Distrust: Political Inference from the Great Chinese Famine. 2015. Available online: https:/ / ssrn.com/abstract=2652587 (accessed on 4 February 2017).

44. Gao, Q.; Wu, S.; Zhai, F. Welfare participation and time use in China. Soc. Indic. Res. 2015, 124, $863-887$. [CrossRef]

45. Gustafsson, B.; Shi, L.; Sato, H. Data for studying earnings, the distribution of household income and poverty in China. China Econ. Rev. 2014, 30, 419-431. [CrossRef]

46. Li, L.; Wu, X. Housing price and entrepreneurship in China. J. Comp. Econ. 2014, 42, 436-449. [CrossRef]

47. Sun, Y.; Shang, J. Factors affecting the health of residents in China: A perspective based on the living environment. Ecol. Indic. 2015, 51, 228-236. [CrossRef]

48. Yuan, H. Structural Social Capital, Household Income and Life Satisfaction: The Evidence from Beijing, Shanghai and Guangdong-Province, China. J. Happiness Stud. 2016, 17, 569-586. [CrossRef]

49. Miller, A.H. Political issues and trust in government: 1964-1970. Am. Political Sci. Rev. 1974, 68, 951-972. [CrossRef]

50. Miller, A.H. Rejoinder to "Comment" by Jack Citrin: Political Discontent or Ritualism? Am. Political Sci. Rev. 1974, 68, 989-1001. [CrossRef] 
51. Waldron-Moore, P. Eastern Europe at the crossroads of democratic transition: Evaluating support for democratic institutions, satisfaction with democratic government, and consolidation of democratic regimes. Comp. Political Stud. 1999, 32, 32-62. [CrossRef]

52. Bratton, M.; Mattes, R. Support for Democracy in Africa: Intrinsic or instrumental? Br. J. Political Sci. 2001, 31, 447-474. [CrossRef]

53. Seligson, M.A. Trouble in Paradise? The erosion of system support in Costa Rica, 1978-1999. Lat. Am. Res. Rev. 2002, 37, 160-185.

54. Sarsfield, R.; Echegaray, F. Opening the black box: How satisfaction with democracy and its perceived efficacy affect regime preference in Latin America. Int. J. Public Opin. Res. 2006, 18, 153-173. [CrossRef]

55. Avery, J.M. The sources and consequences of political mistrust among African Americans. Am. Political Res. 2006, 34, 653-682. [CrossRef]

56. Avery, J.M. Race, partisanship, and political trust following Bush versus Gore (2000). Political Behav. 2007, 29, 327-342. [CrossRef]

57. Weitz-Shapiro, R. The local connection: Local government performance and satisfaction with democracy in Argentina. Comp. Political Stud. 2008, 41, 285-308. [CrossRef]

58. Li, L. Distrust in government leaders, demand for leadership change, and preference for popular elections in rural China. Political Behav. 2011, 33, 291-311. [CrossRef]

59. Ma, G.; Rui, O.M.; Wu, Y. A springboard into politics: Do Chinese entrepreneurs benefit from joining the government-controlled business associations? China Econ. Rev. 2015, 36, 166-183. [CrossRef]

60. Chen, J.; Davis, D.S.; Wu, K.; Dai, H. Life satisfaction in urbanizing China: The effect of city size and pathways to urban residency. Cities 2015, 49, 88-97. [CrossRef]

61. Fan, G.; Wang, X.; Zhu, H. NERI Index of Marketization of China's Provinces 2009 Report; Economic Science Press: Beijing, China, 2011.

62. Belsley, D.A. Conditioning Diagnostics; John Wiley \& Sons: New York, NY, USA, 1991.

63. Li, L. Political trust in rural China. Mod. China 2004, 30, 228-258. [CrossRef]

64. Espinal, R.; Hartlyn, J.; Kelly, J.M. Performance still matters: Explaining trust in government in the Dominican Republic. Comp. Political Stud. 2006, 39, 200-223. [CrossRef]

65. Catterberg, G.; Moreno, A. The individual bases of political trust: Trends in new and established democracies. Int. J. Public Opin. Res. 2006, 18, 31-48. [CrossRef]

66. Rigobon, R. Identification through heteroskedasticity. Rev. Econ. Stat. 2003, 85, 777-792. [CrossRef]

67. Lewbel, A. Using heteroscedasticity to identify and estimate mismeasured and endogenous regressor models. J. Bus. Econ. Stat. 2012, 30, 69-80. [CrossRef]

68. Eichengreen, B.; Panizza, U. A surplus of ambition: Can Europe rely on large primary surpluses to solve its debt problem? Econ. Policy. 2016, 31, 5-49. [CrossRef]

69. Denny, K.; Oppedisano, V. The surprising effect of larger class sizes: Evidence using two identification strategies. Labour Econ. 2013, 23, 57-65. [CrossRef]

70. Gong, G.; Xu, S.; Gong, X. On the Value of Corporate Social Responsibility Disclosure: An Empirical Investigation of Corporate Bond Issues in China. J. Bus. Ethics. 2016. [CrossRef]

71. Ivanov, I.T.; Santos, J.A.; Vo, T. The transformation of banking: Tying loan interest rates to borrowers' CDS spreads. J. Corp. Finance. 2016, 38, 150-165. [CrossRef]

72. Anderson, C.J.; Tverdova, Y.V. Corruption, political allegiances, and attitudes toward government in contemporary democracies. Am. J. Political Sci. 2003, 47, 91-109. [CrossRef]

73. Iyengar, S. Subjective political efficacy as a measure of diffuse support. Public Opin. Q. 1980, 44, $249-256$. [CrossRef]

74. Miller, A.; Listhaug, O. Political Performance and Institutional Trust. Oxford University Press: Oxford, UK, 1999.

75. Seligson, M.A. The impact of corruption on regime legitimacy: A comparative study of four Latin American countries. J. Political. 2002, 64, 408-433. [CrossRef]

76. Kaase, M. Interpersonal trust, political trust and non-institutionalised political participation in Western Europe. West Eur. Political. 1999, 22, 1-21. [CrossRef]

77. Buonanno, P.; Montolio, D.; Vanin, P. Does social capital reduce crime? J. Law Econ. 2009, 52, $145-170$. [CrossRef]

78. Wu, W.; Firth, M.; Rui, O.M. Trust and the provision of trade credit. J. Bank. Finance. 2014, 39, 146-159. [CrossRef] 
79. Lehrer, E.L. Religion as a determinant of economic and demographic behavior in the United States. Popul. Dev. Rev. 2004, 30, 707-726. [CrossRef]

80. Arbuckle, M.B.; Konisky, D.M. The role of religion in environmental attitudes. Soc. Sci. Q. 2015, 96, 1244-1263. [CrossRef]

81. Harris, F.C. Something within: Religion as a mobilizer of African-American political activism. J. Political. 1994, 56, 42-68. [CrossRef]

82. Chen, D.; Hu, X.; Liang, S.; Xin, F. Religious tradition and corporate governance. Econ. Res. J. 2013, 59, 71-84. (In Chinese)

83. Du, X.; Jian, W.; Zeng, Q.; Du, Y. Corporate environmental responsibility in polluting industries: Does religion matter? J. Bus. Ethics. 2014, 124, 485-507. [CrossRef]

84. Weber, M. The Religion of China: Confucianism and Taoism; Free Press: Glencoe, IL, USA, 1951.

85. Delhey, J.; Newton, K. Predicting cross-national levels of social trust: Global pattern or Nordic exceptionalism? Eur. Sociol. Rev. 2005, 21, 311-327. [CrossRef]

86. Tan, S.J.; Tambyah, S.K. Generalized trust and trust in institutions in Confucian Asia. Soc. Indic. 2011, 103, 357-377. [CrossRef]

87. Du, X. Does religion mitigate tunneling? Evidence from Chinese Buddhism. J. Bus. Ethics. 2014, 125, $299-327$. [CrossRef]

88. Munro, N. Profiling the victims: Public awareness of pollution-related harm in China. J. Contemp. China. 2014, 23, 314-329. [CrossRef]

89. Bhattacharya, N.; Ecker, F.; Olsson, P.M.; Schipper, K. Direct and mediated associations among earnings quality, information asymmetry, and the cost of equity. Acc. Rev. 2011, 87, 449-482. [CrossRef]

90. Inglehart, R.; Norris, P. Rising Tide: Gender Equality and Cultural Change around the World; Cambridge University Press: Cambridge, UK, 2003.

91. Edelstein, M.R. Contaminated Communities: The Social and Psychological Impacts of Residential Toxic Exposure; Westview Press: Boulder, USA, 1988.

92. Fiorina, M.P. Economic retrospective voting in American national elections: A micro-analysis. Am. J. Political Sci. 1978, 22, 426-443. [CrossRef]

93. MacKuen, M.B.; Erikson, R.S.; Stimson, J.A. Peasants or bankers? The American electorate and the US economy. Am. J. Political Sci. 1992, 86, 597-611. [CrossRef] 